\title{
Corporate Finance In Europe Confronting Theory With Practice
}

Dirk Brounen, Abe de Jong and Kees Koedijk

\begin{tabular}{|l|l|}
\hline \multicolumn{2}{|l|}{ ERIM REPORT SERIES RESEARCH IN MANAGEMENT } \\
\hline ERIM Report Series reference number & ERS-2004-002-F\&A \\
\hline Publication & January 2004 \\
\hline Number of pages & 41 \\
\hline Email address corresponding author & ckoedijk@fbk.eur.nl \\
\hline URL & https://ep.eur.n/handle/1765/1111 \\
\hline Address & Erasmus Research Institute of Management (ERIM) \\
& Rotterdam School of Management / Rotterdam School of \\
& Economics \\
& Erasmus Universiteit Rotterdam \\
& P.O. Box 1738 \\
& 3000 DR Rotterdam, The Netherlands \\
& Phone: + 31 10 408 1182 \\
& Fax: +31 10 408 9640 \\
& Email: info@erim.eur.nl \\
& Internet: www.erim.eur.nl \\
\hline
\end{tabular}

Bibliographic data and classifications of all the ERIM reports are also available on the ERIM website: www.erim.eur.nl 


\title{
ERASMUS RESEARCH INSTITUTE OF MANAGEMENT
}

\author{
REPORT SERIES \\ RESEARCH IN MANAGEMENT
}

\begin{tabular}{|c|c|c|}
\hline \multicolumn{3}{|c|}{ BIBLIOGRAPHIC DATA AND CLASSIFICATIONS } \\
\hline Abstract & \multicolumn{2}{|c|}{$\begin{array}{l}\text { In this paper we present the results of an international survey among } 313 \text { CFOs on capital } \\
\text { budgeting, cost of capital, capital structure, and corporate governance. We extend previous } \\
\text { results of Graham and Harvey (2001) by broadening their sample internationally, by including } \\
\text { corporate governance, and by applying multivariate regression analysis. We document } \\
\text { interesting insights on how theoretical concepts are applied by professionals in the U.K., the } \\
\text { Netherlands, Germany, and France and compare these results with the U.S. We discover } \\
\text { compelling variations between large and small firms across all markets. While large firms } \\
\text { frequently use present value techniques and the capital asset pricing model when assessing the } \\
\text { financial feasibility of an investment opportunity, CFOs of small firms still rely on the payback } \\
\text { criterion. Regarding debt policy we document more subtle disparities across firms and national } \\
\text { samples. We also find substantial variation in corporate governance structures, which turn out } \\
\text { to be more oriented at shareholder wealth in the Anglo-Saxon countries. Corporate finance } \\
\text { practice appears to be influenced mostly by firm size, to a lesser extent by shareholder } \\
\text { orientation, while national differences are weak at best. }\end{array}$} \\
\hline \multirow{3}{*}{$\begin{array}{l}\text { Library of Congress } \\
\text { Classification } \\
\text { (LCC) }\end{array}$} & $5001-6182$ & Business \\
\hline & $4001-4280.7$ & Finance Management, Business Finance, Corporation Finance \\
\hline & HG 4001+ & Financial Management \\
\hline \multirow{3}{*}{$\begin{array}{l}\text { Journal of Economic } \\
\text { Literature } \\
\text { (JEL) }\end{array}$} & M & Business Administration and Business Economics \\
\hline & G 3 & Corporate Finance and Governance \\
\hline & G 31 & Capital budgeting \\
\hline \multirow{3}{*}{$\begin{array}{l}\text { European Business Schools } \\
\text { Library Group } \\
\text { (EBSLG) }\end{array}$} & $85 \mathrm{~A}$ & Business General \\
\hline & $220 \mathrm{~A}$ & Financial Management \\
\hline & $220 \mathrm{H}$ & Capital budgeting \\
\hline \multicolumn{3}{|c|}{ Gemeenschappelijke Onderwerpsontsluiting (GOO) } \\
\hline \multirow[t]{3}{*}{ Classification GOO } & 85.00 & Bedrijfskunde, Organisatiekunde: algemeen \\
\hline & 85.30 & Financieel management, financiering \\
\hline & 85.30 & Financieel management, financiering \\
\hline \multirow[t]{3}{*}{ Keywords GOO } & \multicolumn{2}{|c|}{ Bedrijfskunde / Bedrijfseconomie } \\
\hline & \multicolumn{2}{|c|}{ Financieel management, bedrijfsfinanciering, besliskunde } \\
\hline & \multicolumn{2}{|c|}{$\begin{array}{l}\text { Financieel management, Bedrijfsgrootte, Corparate Governance, Vergelijkende economie, } \\
\text { Europa }\end{array}$} \\
\hline Free keywords & \multicolumn{2}{|c|}{$\begin{array}{l}\text { International economics, financial economics, law and economics, corporate governance, cost } \\
\text { of capital, capital structure }\end{array}$} \\
\hline
\end{tabular}




\title{
CORPORATE FINANCE IN EUROPE Confronting Theory with Practice
}

\author{
Dirk Brounen \\ Rotterdam School of Management \\ Erasmus University Rotterdam \\ Abe de Jong \\ Rotterdam School of Management \\ Erasmus University Rotterdam \\ Kees Koedijk \\ Rotterdam School of Management \\ Erasmus University Rotterdam \\ CEPR
}

Current D raft: January 2004

Keywords: international economics, financial economics, law and economics, corporate governance, cost of capital, capital structure

JEL Classification Numbers: G31, G 32

Correspondence to: Kees Koedijk, Erasmus University Rotterdam, Department of Financial Management, P.O. Box 1738, 3000 DR, Rotterdam, The Netherlands, ckoedijk@ fbk.eur.nl.

Supplementary research results are available at http:// web.eur.nl/fbk/ dep/ dep5/ research

The authors would like to thank Mark Flood and Campbell Harvey for thelr helpful comments on a previous version of this paper and we thank the Vereniging Trustfonds Erasmus Universiteit Rotterdam for their financial support. All remaining errors are the responsibility of the authors. 


\title{
CORPORATE FINANCE IN EUROPE Confronting Theory with Practice
}

\begin{abstract}
In this paper we present the results of an international survey among $313 \mathrm{CFO}$ s on capital budgeting, cost of capital, capital structure, and corporate governance. We extend previous results of Graham and Harvey (2001) by broadening their sample internationally, by including corporate governance, and by applying multivariate regression analysis. We document interesting insights on how theoretical concepts are applied by professionals in the U.K., the Netherlands, Germany, and France and compare these results with the U.S. We discover compelling variations between large and small firms across all markets. While large firms frequently use present value techniques and the capital asset pricing model when assessing the financial feasibility of an investment opportunity, CFO s of small firms still rely on the payback criterion. Regarding debt policy we document more subtle disparities across firms and national samples. We also find substantial variation in corporate governance structures, which turn out to be more oriented at shareholder wealth in the Anglo-Saxon countries. Corporate finance practice appears to be influenced mostly by firm size, to a lesser extent by shareholder orientation, while national differences are weak at best.
\end{abstract}




\section{Introduction}

Over the last century academics from around the globe have worked on postulating models and theories enabling firms to enhance the efficiency of their financial management operations. Nobel price winning concepts like the capital asset pricing model and capital structure theorems have been praised and taught in class rooms, but to what extent these celebrated notions have also found their way into corporate board rooms remains somewhat opaque. In this paper we attempt to narrow the gap between scientists and professionals by conducting a survey on how professionals deal with different dilemmas within modem financial management. We measure the extent to which theoretical concepts have been adopted by professionals from a wide range of firms from the U.K., the Netherlands, Germany, and France. We also compare our results with the previous findings of $\mathrm{G}$ raham and Harvey (2001) for a similar sample of U.S. firms.

Our study focuses on non-U.S. companies, offering a rare possibility to test whether previous results of Graham and Harvey (2001) also hold outside the United States. Recent studies have documented fundamental differences between the financial markets and systems when comparing the United States with Europe. La Porta et al $(1997,1998)$ focus on the underlying disparities between the legal systems encompassing both continents. Their results show how common law and civil law countries diverge with respect to protecting investors and thereby causing significant distinctions between both financial markets. Rajan and Zingales (2003) stress the continental differences by comparing the polar forms of financial systems: the institution-heavy relationship-based, more prevalent in Europe, and the marketintensive arm's-length, more prevalent in the United States. Although the European market appears to be switching to the arms'-length system, compelling variations between both continental financing policies remain. Finally, from a corporate governance perspective, Chew (1997) shows how the Anglo-Saxon marked-based corporate governance system significantly differs from the relation-based or insider system, which is most widespread in Europe. In this study we also investigate the effect of the corporate governance system on an individual firm level and include this important issue in our overall analysis of European corporate finance practices. The recent stream of literature tends to infer a similar conclusion; the U.S. and the European financial markets and firms differ considerably. We contribute to the debate by comparing the corporate finance practice of individual firms in both continental markets. We test whether the apparent differences in institutional settings translate into significantly different financial management practices.

In order to confront theory with the behaviour of financial managers in practice we apply survey research. We analyse a wide range of corporate finance issues, ranging from capital budgeting techniques to capital structure, and corporate governance, which allows us to link the different issues and thereby deepen our analysis. Furthermore, we analyze the responses in our survey conditional on firm specific characteristics. This enables us to test whether these factors drive the results. We sample a cross-section of 6,500 companies from the U.K., the Netherlands, France, and Germany. We collected 313 responses creating a sample size, which represents the second largest survey sample in the financial literature. ${ }^{-}$Survey research is

${ }^{1}$ The Graham and Harvey (2001) study analyses a sample of 392 U.S. CFO s, the second largest published survey by our knowledge was by Moore and Reichert (1983) containing data on 298 large firms from the U.S. Bancel 
relatively rare within the empirical corporate finance literature, where most studies are based on large samples of financial observations. Although these large samples offer cross-sectional variations and the statistical power to analyze these variations, they are hampered with respect to the specification and are limited to dealing with quantifiable issues. In our survey approach we use a relatively large sample combined with the ability to ask qualitative questions. Besides these opportunities, survey research is associated with some limitations. We measure beliefs rather than actions and therefore we might be confronted with respondence biases. We carefully take this drawback into consideration when composing our samples and constructing our questionnaire, such that this bias will be limited to the minimum. Although this type of field studies is rare, some path-breaking studies have preceded our endeavour. However, the vast majority of the available financial field studies focuses on large U.S. firms and often is concerned with just one specific corporate finance issue at a time.

Our study enriches the findings of Graham and Harvey (2001) in three manners. Firstly, by employing an international sample we are able to assess whether existing insights also hold outside the U.S. Secondly, we incorporate questions which address the corporate governance policy of firms. This enables us to investigate whether cross-national differences in corporate governance policies influence the way in which firms organize their financial management. Finally, we extend the existing literature by applying multivariate regression analysis in order to explain the cross-sectional variation in corporate finance practices. The multivariate regressions offer a better explanation of the responses than uni-variate comparisons, because we can measure the effect of a variable conditional on the influence of others. This approach enables us to test whether country effects or firm characteristics dominate the explanation of corporate financial management policies.

O ur results with respect to capital budgeting show that European firms are still remarkably keen on applying the payback criterion, instead of discounting their cash flows using the internal rate of return or the net present value. Alike their U.S. colleagues, European CFOs determine their cost of capital using the CAPM, rather than applying arithmetic average historic returns or the dividend discount model. O verall we notice that firm size is positively related to the use of discounted cash flow methodology, the application of CAPM and maintaining a target debt ratio. Smaller firms, and firms oriented less towards maximizing shareholder value are more likely to evaluate their investment opportunities using the payback period criterion and set their cost of capital on whatever their investors tell them. Finally, concerning the capital structure we find low disparities between corporate debt policies. In all four national samples respondents report financial flexibility to be the key factor when determining their debt structure, a result which corroborate with previous studies from the U.S. O ur main results indicate that corporate financial management practices are predominantly determined by firm size, to a lesser extent by shareholder orientation, and much less by country of origin.

and Mittoo (2003) survey CFO s from 87 companies, originating from 16 different European countries, on their corporate debt policy, which represents the largest European survey study so far. A recent survey by Brav et al. (2003) on payout policy in the U.S. includes 384 respondents.

${ }^{2}$ The most famous survey study in the recent financial literature is by G raham and Harvey (2001), a paper, which was awarded the Jensen Price for the best paper published in the Journal of Financial Economics in 2001. Other seminal survey papers in the field of corporate finance are Lintner (1956) and Billingsley and Smith (1996). 
The paper is organized as follows. In the next section, we present the sample collection procedures and sample statistics. Section three offers a comprehensive overview of our results on capital budgeting. Section four deals with the common practice regarding the cost of capital, while section five focuses on our results on capital structure. Finally we offer concluding remarks in section six.

\section{Data and methodology}

\subsection{Sample collection prooedures}

Our survey includes four groups of questions. First, we include several questions to describe the firm and its CEO. Second pose questions on capital budgeting techniques. Third, we investigate cost of capital estimations and continue our analysis by focusing on capital structure policy. Finally, we conclude our questionnaire by asking firms about their goals and their perception of the importance of different stakeholders. The starting point for our questionnaire is the survey of Graham and Harvey (2001). In order to facilitate a fair comparison of both sets of survey results, we ask exactly the same questions. In addition we add questions on the firm's goals and stakeholders.

We first prepared the survey to be send to firms in the U.K., the Netherlands, Germany and France. First, the survey of Graham and Harvey (2001) has been translated into German and French by a certified translation agency and into Dutch by the authors. Next, in order to test whether the translations were correct and whether the wording was understood, we conducted several interviews in each of the four countries. In these interviews potential respondents first filled in the questionnaire, and discussed each question afterwards. We learned that the average time to fill out the questionnaire was about 15 minutes. We adjusted some of the wording and added brief explanations, based on the interviewees' feedback. Since we shared the concern of Graham and Harvey in that respondents might fill in only the first two pages of the questionnaire, we controlled for this potential bias by sending out two versions in each language with questions 11-14 and 1-4 interchanged. We expect this to result in a fair distribution of answers on each question in the survey.

We use the Amadeus dataset of Bureau Van Dijk as our sample universe, which covers public and private firms in Europe. From this database we selected all firms with 25 or more employees. In addition we use the Kompass database with names and positions of the highranked officials. We search for the name of the CFO in the Kompass data for each firm in the Amadeus data. O ur goal is to select 2000 firms in the U.K., G ermany and France, and 500 firms in the Netherlands. We first select all public firms in each country. Then we select all private firms of which we know the name of the CFO. Finally, we complement our sample sets with randomly chosen private firms.

The questionnaire was set out by a third party, ensuring that the results are handled anonymously, thereby stimulating the respondents to answer our questions frankly. In the period of November 1 to 8, 2002 the questionnaires were sent by mail to the sample firms. Each firm received a cover letter, the four-page questionnaire, a pre-stamped envelop and a response form to request a free report of the results. The latter serves as an incentive to fill in the questionnaire. The respondents were offered the opportunity to return their form both by 
mail or by fax. About two weeks after the firms have received the questionnaire all nonrespondents were contacted by phone by native speakers, reminding them to return the questionnaire. D uring the phoneconversation the respondents could go through the questions over the phone immediately or receive a link to a web page for filling in the questionnaire by email. This telephonic and email effort lasted until January 7, 2003 and we received our last response on January 30, 2003.

In total, we received 313 responses, 68 in the U.K., 52 in the Netherlands, 132 in Germany and 61 in France. We received 50.5\% of the questionnaires by mail or fax, $19.2 \%$ by telephonic interviews and 30.3\% through the web page. We analysed our results with regard to potential response biases, which threat survey research. Overall we find that our sample is representative of the overall universe of firms and we detect only a small variation in answers based on the response technique. The overall response rate is $5 \%$, which is somewhat lower than studies like Trahan and Gitman (1995) and Graham and Harvey (2001), which obtained a $12 \%$ and $9 \%$ response rate respectively. However, given the length and depth of our questionnaire and the vast size of our sample we feel confident when analysing our results.

\subsection{Corporate governance characteristics}

La Porta et al. (1998) describe institutional details for 49 different countries, including the five countries, which are part of our study. Their results clearly show that external capital is most important in the U.S., U.K. and the Netherlands. The importance of the capital markets in the U.S. and U.K. is further stressed by the large number of listed firms and IPOs per million inhabitants. Furthermore, La Porta et al. (1998) report cross-national statistics on the power of shareholders and creditors, using a anti-director index. This anti-director index measures the power of shareholders, which is much higher in the Anglo-Saxon countries. Finally, creditor rights also differ substantially across countries in our sample and illustrate the large variation in institutional settings.

In order to incorporate these fundamental differences in national market characteristics properly, we included questions on corporate governance, i.e. important stakeholders and company goals. By doing so we test whether the individual firms in our sample reflect the institutional variations presented in La Porta et al. (1998) and we can control for these variations in our further analysis. First we ask our respondents which goals their companies aim to achieve. Panel A of Figure 1 clearly shows that in all countries firms aim at maximizing their profits, sustainable growth, and market position, while solvability and dividends are associated with lower priorities. The most prominent distinction is reported with respect to the goal of maximizing shareholder wealth. While Dutch and British firms declare to consider shareholder wealth as one of their top priorities, French and German firms consider this goal even less important than optimising their solvability. In order to extend our analysis on this

\footnotetext{
3 We performed several experiments in order find out whether our results are affected by nonresponse bias. First we clustered our results along the way in which the responses have been received (mail or fax, telephone and internet) and analysed both the average responses and the distributions within each cluster. On a 5\% significance level we reported a significant difference in means across clusters for only 19 out of the 133 questions and statements, which are included in our survey. Furthermore we follow the example of Moore and Reichert (1983) by comparing characteristics like firm size, industrial distribution, and public status of the responding firms to the population at large. Again we find no statistically significant differences between the two groups on a 5\% confidence level and therefore we may consider our sample to be representing the population.
} 
phenomenon we asked an additional question regarding stakeholder importance. The outcomes, which are presented in Panel B, exhibit the typical pattern in which customers are regarded most important in each country. Regarding shareholder and debtholder importance the results are more scattered and clearly show that firms in the U.K. and the Netherlands consider their supplier of capital to be much more important than their colleagues from France and Germany. French and German firms consider the general public to be more important to them than their financiers.

\subsection{Firm statistics}

Figure 2 presents summary information on the characteristics of the firms in our European samples and compares these with the U.S. firms of Graham and Harvey (2001). The companies in our European sample are smaller on average compared to the U.S. firms of Graham and Harvey. While $51 \%$ of all firms in their U.S. sample have sales exceeding 500 million U.S. dollars, this number is less than $25 \%$ in each European sample. In the subsequent analysis we refer to firms with sales exceeding 1 billion U.S. dollars as large firms'. Regarding the portion of foreign sales we observe the opposite disparity. This component exceeds a quarter of total sales for at least $40 \%$ of each European sample, while U.S. firms exhibited remarkably lower involvement in foreign sales. The distribution across industry types is rather similar in all countries with most firms belonging to manufacturing in each sample. Like Graham and Harvey we document that non-manufacturing firms are spread evenly across other industries in our European samples. With respect to the priceearnings ratios we document slighter lower average values for our European sample. Whereas only $40 \%$ of the U.S. firms reported a price-earnings ratio below 15, our European firms reported this response more frequently ranging between $56 \%$ in France to $67 \%$ in Germany. This result, however, needs to be handled with care given the time difference between both surveys.

Panels E to $G$ of Figure 2 display information concerning corporate debt policy. The longterm debt ratios show that about a quarter of the firms in the U.K. and France posses no long-term debt at all. These firms are financed completely with equity and short-term liabilities. The German firms are over-represented in the 10-19\% interval, while many Dutch firms are in the $20-29 \%$ interval. Subsequently, we define low levered firms as firms with leverage below $30 \%$, while highly levered firms have a debt ratio above $30 \%$. The fractions of firms with low and high leverage are hardly different between the countries. The only exception is France, which is under-represented in the highest interval. This international pattern in leverage complies with previous studies of Rajan and Zingales (1995) and De Bondt (1998), who documented similar national differences and explained them by emphasizing the institutional differences and the importance of indirect credit markets. Regarding the presence of a target debt ratio, Panel $\mathrm{F}$ shows lower values for our European samples compared to previous U.S. results. $65 \%$ of the firms in the French sample report to have no debt target. We have split up our samples along target ratios and refer to firms, which declared to have flexible, strict or tight target ratio, as 'target ratio' in the subsequent analysis. The percentage of firms that considered issuing equity differs substantially between the three countries with relatively better developed public capital markets (U.S., U.K. and Netherlands) and the other countries. The percentage of firms that considered issuing debt is quite similar. 
The only exception is the low percentage of German firms considering a convertible debt issue.

The next component of our summary statistics concerns the CEOs background. On average, our results indicate that European CEOs in our sample are slightly younger than their U.S. colleagues. Regarding their tenure the variation is less compelling. The most remarkable result regarding tenure stems from France, where CEO s appear to stay with their firms for significantly longer time periods than their colleagues from other markets. Concerning the level of education of the surveyed CEOs our results show comparable patterns. Compared to their U.S. colleagues a smaller portion of our European CEOs quit their studies after their undergraduate, and slightly higher portion has acquired an MBA masters, except for the U.K where MBAs are rare. Finally, when it comes to executive stock ownership our results show very little evidence for cross-national patterns. In each sample the vast majority of firms responded that their executives own less than $5 \%$ of the firms' shares.

Finally, we gathered some summary statistics regarding the public or private status of the company, the dividend policy, and credit rating, of which the key results are presented in Panel A of Table 1. Like the U.S. firms in Graham and Harvey's study, most of our European firms are not utilities, pay dividends, and have an investment grade rating. The most remarkable difference is that contrary to the U.S. firms our European firms are mostly private, although the difference in distribution is still relatively small.

\section{Capital budgeting techniques}

\subsection{D esign}

This section examines the way in which European firms evaluate investment projects. We carefully consider the underlying firm characteristics in order to link the results to differences in, for example, firm size and CEO education. In line with Graham and Harvey (2001) we include a wide variety of capital budgeting techniques, including discounted cash flow techniques like; the IRR, the NPV, the adjusted present value (see Brealey and Myers, 2003), the discounted payback period, the profitability index, and hurdle rates next to simple price earning multiples, book rates of return and more advanced methods like sensitivity analysis, real options and value at risk. Respondents are asked to score how frequently they use the different capital budgeting techniques on a scale of 0 to 4 (0 meaning never, 4 meaning always) and we display the main results in Table 2.

\subsection{Results}

Most European respondents select payback period as their most frequently used capital budgeting technique. In the U.K., the Netherlands, G ermany and France respectively $69.2 \%$, $64.7 \%, 50.0 \%$ and $50.9 \%$ of CFO s use the payback period as their favourite tool. Of the U.S. firms of Graham and Harvey $56.7 \%$ declared to be using this payback rule, but there it came in only as third most popular tool after the internal rate of return and the net present value. In Europe the payback period criterion is immediately followed by the net present value and internal rate of return methods. In the U.K., the Netherlands, Germany and France respectively $53.1 \%, 56.0 \%, 42.2 \%$ and $44.1 \%$ of all CFOs use the internal rate of return 
method while $47.0 \%, 70.0 \% 47.6 \%$ and $35.1 \%$ of all CFOs in these countries rely on the net present value method.

The relative popularity of the payback period in Europe is surprising, because financial textbooks have discussed the shortcomings of the payback criterion for many decades. As is well known the payback ignores the time value of money and cash flows beyond the cut-off date. It is sometimes argued that the payback approach is rational for severely capital constrained firms: if an investment project does not pay positive cash flows early on, the firms will cease the operation and therefore can not receive positive cash flows that occur in the distant future. We do not find any evidence to support this claim. When taking firm characteristics into account we notice that the use of the payback criterion is more popular among smaller firms (except for the U.K.) and among firms with management belonging to the highest age cluster. The NPV is used significantly more often by large firms and by firms, managed by a CEO with an MBA (except for the U.K.). Here we also might find an explanation for the difference between our European results and the U.S. outcomes of Graham and Harvey, since we already noted that our European firms tend to be somewhat smaller on average. When accounting for cross-sectional variation in shareholder orientation, we find that firms that reported to maximize shareholder value are also the firms that prefer to use discounting techniques instead of the plain payback criterion. ${ }^{4}$ Theory shows that this indeed enhances shareholder wealth.

\section{Cost of capital}

\subsection{Results}

The first question we asked regarding cost of capital is whether firms compute this cost explicitly. The response to this question exhibits a very limited cross-national variation, i.e. $64 \%$ in the U.S., $57 \%$ in the U.K., $60 \%$ in the Netherlands, $59 \%$ in France, and $53 \%$ in Germany.

We continue our analysis by focusing on the firms, which responded positively, by first asking them how they compute their cost of capital. We explore whether firms use the capital asset pricing model (CAPM), a multi-beta CAPM (with extra risk factors in addition to the market beta), average historical returns, a dividend discount model, or whether they simply apply the average historic return on common stocks or whatever their investors tell them they require. The results in Table 3 indicate that the CAPM is the most popular method of estimating the cost of equity capital in Europe: in the U.K., Netherlands, Germany and France, $47.1 \%, 55.6 \%, 34 \%$, and $45.2 \%$ of CFO s relies on the CAPM for estimating the cost of equity. Although the CAPM is a popular method in Europe, our results also show that this popularity is low compared to the U.S. G raham and Harvey (2001) report that almost 73.5\% of U.S. CFO s relies to some extent on the CAPM when estimating the cost of equity capital. In Europe, this percentage is considerably lower and equals around $45 \%$ on average. In line with the U.S. results, the second and third popular methods for the European countries are respectively the use of average historical returns and the use of some version of a multi-beta

${ }^{4}$ We analyse sample splits based on several firm characteristics. In Tables 2 and 5 we present the results for size and CEO education, all remaining split ups are displayed on our website. 
CAPM. Again the percentages for the European countries are substantially lower. The differences between the U.S. results and the Netherlands, German and French results are especially remarkable. A sound explanation for this discrepancy might be the public or private status of a firm. In our cross-sectional analysis we find that in each national sample public firms are more likely to use the CAPM for deriving their cost of capital while private firms use whatever their investors tell them. This difference is rational, since public firms have stock prices at their disposal, which they will need to run the CAPM properly. Due to the absence of public stock returns, private firms prefer to use whatever investors tell them when discounting their cash flows. In the Netherlands, Germany and France the percentages for this category vary between $44.8 \%, 39.2 \%$ and $34.4 \%$. In the Netherlands and France this method is the second most popular after the CAPM. In Germany this category is even the most popular method and outperforms the CAPM as method for obtaining an estimate for the cost of capital. Remarkably enough, we do not find a consistent relationship between shareholder orientation and the computation of the cost of equity. Although shareholder oriented firms appear to be using "whatever our investors tell us they require" more often in most cases, the differences in results is insignificant and lacks robustness.

When considering the underlying firm characteristics we notice that CAPM is consistently more popular among large firms, and among firms with relatively high proportions of foreign sales. The same holds for the more advanced CAPM alternatives in which additional risk factors are included, this too is used mostly by large companies and by firms with relatively high leverage. This indicates that large, public firms are more inclined to apply more sophisticated techniques when setting their cost of capital, whereas small firms rely on rules of thumb. This difference, however, is not a result of a lack of familiarity with the theoretical concepts, since there appears to be no relationship between the age and education of the CEO and the use of theoretical tools like the CAPM. If any, the relationship between the use of CAPM, the firm and the CEO exists, it would be reversed, since CEOs with long tenures are using CAPM more frequently. Apparently CEOs learn to appreciate the use of CAPM while they are in charge of the company, which implies that CAPM requires a critical mass (size), a public listing and an experienced CEO .

\subsection{Specific risk factors}

After acknowledging the basic concepts that are being applied when deriving the overall cost of equity capital, we now turn to the explicit analysis of individual projects. We identify a wide variety of specific risk factors, which might be of importance when evaluating an individual project. These factors include: interest rate risk, foreign exchange risk, business cycle risk, unexpected inflation, commodity price risk, term structure risk, and distress risk. In line with the work of Fama and French (1992) and Jegadeesh and Titman (1993) we also include the fundamental factors size, value, and momentum.

We ask our respondents whether they take these individual factors into account when valuing projects, and if so whether they do this by adjusting their discount rate, the cash flow estimations or both. We display our key results in Table 4.

Overall, we document a strong tendency for omitting most of the specific risk factors. This result complies with the average response of U.S. companies to the same issue. The vast majority of firms does not take specific risk factors into account when evaluating individual 
investment projects. If any, firms tend to consider interest rate-, and currency risk and in most of those cases where they do acknowledge these risks, they absorb them by adjusting either the discount rates or the cash flows. Momentum is considered only by a small minority, except for France where 27.8\% of our respondents claims to adjust their discount rate based on recent stock price performance. Furthermore we notice that $26.3 \%$ of $\mathrm{G}$ erman companies and a remarkable $46.6 \%$ of French companies is prone to amend cash flow estimations according to their perception of commodity price risk.

\subsection{Project versus firm risk}

Next we concentrate on the use of discount rates when considering new projects in overseas markets. The U.S. results of G raham and Harvey regarding the use of discount rates have been surprising. The majority of firms in their sample claimed to use the plain vanilla firm discount rate when evaluating new foreign projects. This outcome implies that most companies are not incorporating differences in project risks and foreign markets properly. By posing the same questions to our respondents we would like to find out whether the same management approach is prevailing in Europe.

The main results of this exercise are presented in Table 5 and show even more striking responses. While in the U.S. 58.8\% of all firms indicated to use the discount rate of the entire company opposed to $50.9 \%$, which incorporate project particularities by deriving a riskmatched rate, this difference between these two alternatives is remarkably larger in our European samples. $41.0 \%$ of U.K. firms, $64.6 \%$ of D utch firms, $42.0 \%$ of German firms and $24.1 \%$ of French firms apply company rates, while as little as $23.7 \%$ of U.K. firms, $27.1 \%$ of Dutch firms, $25.0 \%$ of G erman firms and 27.3\% make use of a risk-matched project rate of retum. Alike the U.S. the remaining three altematives, the use of a discount rate for the overseas market, a divisional discount rate, or a different rate for each component cashflow that has a different risk characteristic, is almost never used in each European sample.

Large firms are more likely to apply these theoretically more sound risk-matched rates. Except for the Netherlands we also find that the CEOs' education tends to increase the likelihood of the usage of risk-matched projects rates. Contrary to Graham and Harvey our results show that the more complicated alternatives of discounting new projects are applied more by higher educated CEO s consistently throughout all our national samples. Regarding the age of the $\mathrm{CEO}$ s in charge we notice that the simple company-wide discount rate is being applied mostly by the oldest $\mathrm{CEO}$ s, while the more complicated project specific rates tend to be used more often by younger CEOs. A similar variation is found when looking into the shareholder orientation of the firms involved. Firms that declare to maximize their shareholders' wealth, tend to use more complicated firm specific rates. Since we pose the questions regarding new projects in overseas markets we also explicitly take foreign sales into account when interpreting the responses. In line with the results of Graham and Harvey we find no evidence that firms with foreign sales make use of more sophisticated discounting schemes. These intemational operating firms tend to rely on company discount rates in most cases as well.

In summary, our results show an interesting variation in cost of capital practices. In line with Graham and Harvey we document CAPM to be the most popular tool when computing the cost of capital among the firms, which discount their cash flow estimates. However, this 
result varies along firm size and appears to depend on whether firms are publicly listed. Large, publicly listed firms apply the CAPM on their stock price history, while small, private firms tend to rely on whatever their investors tell them. Furthermore, our results show that the vast majority of firms is likely to use a company cost of capital for evaluating their individual projects, instead of incorporating specific risk factors explicitly. Again we find that this tendency to use company discount rate differs along the size dimension, in which large firms are more likely to risk-matched discount rates when evaluating new projects.

\subsection{Multivariate regression analysis}

In order to deepen our analysis we run a set of multivariate probit regressions in which we can compare the impact of various explanatory variables on the four most important capital budgeting issues. This way we try to discover which factors determine whether firms apply DCF-techniques, which type of firms compute the cost of capital and which use CAPM to do so and which type of firms employ sophisticated discount rates? These questions are answered using three sets of model specifications. In the first model we analyze the significance of national variations of our full sample including the U.S. observations of Graham and Harvey (2001) through the use of a set of country dummies, in which the Netherlands serves as omitted variable. In the second model we extend this country analysis by controlling for the cross sectional variation in firm size and the educational level of the CEO using dichotomous variables. In our third and last model we extend the second model by including the level of shareholder orientation of each firm, a variable that is only available for our European sample. We disseminate output of additional model specifications on our weblink.

First, we analyze the use of capital budgeting techniques, our results are displayed in Table 6. We distinguish between the DCF-techniques NPV, IRR, APV, and the discounted payback period (dummy has value 1 if the response to at least one of these four techniques exceeds 2 , and zero otherwise) opposed to the non-DCF-techniques. Model 1 shows that the country dummies reveal significant national differences. $G$ erman and French firms make little use of DCF-techniques, while U.S. firms employ these methods significantly more often than the omitted D utch firms. When including the control variables, size and CEO education, we find that size significantly attributes to explaining the cross sectional variation. Model 3, which exclusively focuses on our European sample, shows stability of the coefficient estimates across continents and reveal, that shareholder orientation is significantly and positively related to the use of D CF-methods. This conclusion confirms our results of Section 3 that lange firms and firms, which have a strong shareholder orientation are more likely to use DCF capital budgeting techniques. In our second set of models we explain which firms compute their cost of capital. The cross-national analysis does not yield any pervasive results. Apparently computing the cost of capital is not induced by nationality. Firm size and shareholderorientation on the other hand tend to increase the likelihood of cost of capital calculations significantly. Among the firms, which compute their cost of capital we differentiate between those who apply CAPM (or an extended CAPM) to do so and the group that uses other technology. We find that German firms use CAPM significantly less on a 10\% confidence level, whereas U.S. firms turn out to be the most frequent users of CAPM. Much of this 
cross-national variation disappears when extending our model 1 with control variables, which show that only firm size appears to be driving the use of CAPM significantly. With respect to the last issue, which discount rate is used when evaluating new projects in overseas markets, we split up our samples into a group that utilizes a sophisticated rate in which risk-matching (on project, division or component level) is applied and a group that simply utilizes a company or country wide discount rate. The results from our first model specification show that U.S. firms are more likely to use a risk-matched discount rate compared to their European competitors. This difference, however, reduces after including the variation in firm size and CEO education. In combination with our results from model 3 we may conclude that larger and shareholder oriented firms are significantly more likely to apply a risk-matched discount rate.

Overall, our results stress the importance of multivariate regressions, because this approach enables us to isolate the impact of variables conditional on other influences. Continental and cross national variations appear to be present but lose much of their impact when controlling for the underlying variation in firm size, CEO education, and shareholder orientation. Capital budgeting and cost of capital dilemmas are influenced most by firm size and the degree of shareholder orientation, both have a significantly positive impact on the issue we raise. Adding these variables significantly helps to increase the fit of the models.

\section{Capital structure}

Our firm statistics already indicated that the overall debt levels in our European samples were low compared to their U.S. competitors. We also showed that in our French sample $65 \%$ of our respondents claimed to have no target debt-ratio of any kind. The combination of both results might indicate that capital structure is considered to be somewhat less important than in corporate America. In this section we analyse the capital structure of our European firms by posing questions with which different capital structure theorems can be tested. First we concentrate on the costs and benefits of debt ratios and the trade-off theory, which balances both. Then we continue our analysis by focusing on asymmetric information motives and agency costs as potential drivers of corporate debt policy. 1 Table 7 describes the factors that determine the appropriate amount of debt in firms. The combination of testing for all these factors should yield us a better understanding of how European firms set their capital structure in practice.

\subsection{T rade off theory of capital structure choice}

\subsubsection{Target debt ratios and the osts and benefits of debt}

The static trade-off theory predicts a trade-off between tax advantages and bankruptcy costs of debt. According to this theory firms balance the beneficial tax shields with the

\footnotetext{
5 We analyse sample splits based on several firm characteristics. In Tables 7, 8, and 9 we present the results for leverage and a target debt ratio, while all remaining split ups are displayed on our website. Figure 2, panel G presents the percentages of firms that seriously considered issuing common stock, convertible debt, and foreign debt. We inquired about the underlying motivations among firms that indicated to consider the issuance. However, the sample sizes are relatively small and we present the results on our website. A discussion of additional results regarding product markets, industry factors, control contests, risk management and cash management considerations is presented on our website.
} 
financial distress costs when determining the appropriate amount of corporate debt. We test this theory by inquiring about the importance of both factors and document that tax advantages of interest deductibility are considered to be only the fourth most important factor in this context, after financial flexibility, credit ratings and earnings volatility. The crossnational variation in this result is modest and indicates that tax advantages are considered to be of equal importance to both in European and U.S. firms. A reassuring discovery is that firms with higher leverage and a target debt ratio are more likely to consider tax advantages of debt an important factor.

The negative effects of debt financing, bankruptcy costs appear to be considered less important when judging by the results in Table 7. On a scale of 0 to 4 , costs of bankruptcy scores range only between 0.65 for France and 1.42 for the Netherlands. Firms with high leverage seem more concerned about these costs, which is an obvious result because their expected bankruptcy costs are larger. The same table shows that the volatility of earnings, which increases the probability of bankruptcy and thus expected costs, is more important. In the U.S., this is the third most important factor as in the U.K. and Germany. In the Netherlands and France, volatility is the second most important factor. Again, the importance of this characteristic is related to high leverage (U.K.) and aiming for a target ratio (U.K., Germany and France). We find no compelling variation across countries or continents. In all countries we find that firms consider bankruptcy costs and tax advantages to be important.

Finally, personal tax effects may offset or increase the tax advantage of debt and thereby impact the optimal balance between corporate tax effects and bankruptcy costs. The low scores in row (f) of Table 7 clearly show that, similar to the U.S., our European firms do not put much weight to the personal tax considerations of their investors. Apparently, firms do not try to attract specific investor clienteles through their capital structure choice. When including the underlying shareholder orientation of firms into this matter, we find that shareholder oriented firms in the Netherlands, France and Germany consider the personal tax issue to be more important than their competitors with low shareholder orientation. These differences, however, are insignificant and are reversed for U.K. firms, indicating that shareholder orientation does not explain much of the cross-sectional variation.

\subsubsection{D eviations from target debt ratios}

O ur firm statistics already indicated that in the U.S. more firms have target ratios, than in the European countries. In the U.K., the Netherlands and G ermany about two-thirds or more of the firms aim for some target debt ratio. However, only one third of the French firms has a target ratio. A striking result is that in each of the countries about 10\% of the firms has a strict target.

Welch (2004) argues that stock returns affect market value debt ratios, because the value of equity changes. Thus, in case firms express their target debt ratios in market values, they will have to rebalance after changes in equity value. We test this hypothesis and the results in row $(\mathrm{g})$ of Table 8 indicate that the scores are indeed much higher in market-oriented countries. The U.S. and U.K. scores of 1.08 and 0.82 , respectively, well exceed the other countries. A plausible explanation for this international variation is that the firms in the latter countries are less likely to be exchange-listed. 
Fisher, Heinkel and Zechner (1989) argue that transaction costs prevent firms from frequently rebalancing their capital structure. Whether transactions costs and fees are important in capital structure choice is shown in Table 7, row (e). This transaction costs hypothesis receives moderate support, with scores ranging between 1.26 for the Netherlands and 1.75 for the U.K. We also ask firms whether they delay the issuance of debt because of transactions costs and fees, but the low values, which are stated in row (e) of Table 8, yield little support for this notion. Apparently transaction costs do not serve as a key driver of corporate debt policy. The subset of firms with a target debt ratios scores significantly higher in several countries in these two questions.

\subsection{A symmetric information ex planations of capital structure}

\subsubsection{Pecking-order model of financing hierarchy}

The pecking-order model of Myers and Majluf (1984) hypothesizes a hierarchy in financing means. First, firms prefer internal financing. Then, external financing is preferred, where debt is preferred over equity. The degree of asymmetric information determines the relative costs of each financing source. Firms that follow this pecking order do not have a target debt ratio, because the ordering determines their preference regarding the issuance of new capital.

Row (g) of Table 7 demonstrates that financial flexibility is the most important factor that influences the amount of debt in each of the five countries. This seems to be evidence of pecking-order behaviour. Later in this section we will discuss this issue in more detail. Our survey includes additional questions related to pecking-order behaviour. In row (a) of Table 8 we inquire whether a debt issue is triggered by insufficient recent profits, the results are weak and scattered, ranging between 1.24 for France and 2.30 for G ermany.

In Table 8, row (d) reports what the score is on debt issues when equity is undervalued. This behaviour would be consistent with pecking-order theory. Compared the 1.56 score in the U.S. our European firms score relatively low. Like Graham and Harvey we find that in large and dividend-paying firms equity valuation is more likely to influence financing decisions. This result nicely illustrates the role of security pricing in public markets, which is much lower in continental Europe.

Overall, our results for the pecking-order model confirm Graham and Harvey's conclusions: results are in line with the predictions of the pecking-order theory. However, given the results on information differences, asymmetries do not drive the pecking order. According to signaling models, firms can signal their quality to investors using their capital

\footnotetext{
${ }^{6}$ Similar weak results are found linking recent profits the considering of the issuance of new equity. For firms that considered issuing equity, we find that the inability of obtaining debt financing is even less important when considering a new equity issue. The amount by which firm's stock is being undervalued or overvalued appears to be more important when considering an equity offer. Firms that seriously consider issuing common stock value the importance of the current stock valuation between 1.69 in the Netherlands and 2.69 in the U.S., making it the second most important consideration (results not reported).
} 
structure decisions. ${ }^{\square}$ Table 8, row (b) illustrates that this motivation scores low, between 0.65 in the Netherlands and 1.06 in France, in all samples when relating it to debt policy.

\subsubsection{A nticipating improvement in credit ratings}

Flannery (1986) argues that managers who expect a higher credit rating than their current rating - because they have superior information - will choose short debt, as their rates for long debt will improve. Table 9, row (e) shows that this argument receives only weak support, only a small minority of all firms in each sample consider this argument to be relevant. The respondents most likely interpreted credit ratings in a broad way, because in continental Europe rating agencies are less active, in comparison with Anglo-Saxon countries. However, the results for this question are similar.

\subsubsection{M ark et timing interest rates}

In the previous section we inquired about timing on the basis of private information within a firm. Managers may also try to time their issues because they expect that economywide interest rates may change. Row (c) of Table 8 yields the surprising result that this is the most important factor in U.S. firms, with a score of 2.22. The scores for the European countries tend to be considerably lower with Germany on the high end with 1.87, whereas Dutch firms report only 1.19 on average.

In Table 9 we ask firms about factors, which affect their choice between short- and longterm debt. Rows (a) and (c) report the influence of expected long and short interest rates in this context and again we find higher values for slightly lower values for our European firms compared to the U.S. results of Graham and Harvey.

\subsection{A gency costs}

\subsubsection{Conflicts between bondholders and equityholders}

The underinvestment problem, as introduced by Myers (1977), is an agency problem between bondholders and shareholder that arises in situations of debt overhang. In firms with good growth opportunities, new projects will not be started if leverage is high. The motivation is that in these situations bondholder will benefit more than the shareholders. In Table 7, row (n) we ask our respondents whether they restrict their borrowing such that profits from new projects can be captured fully by shareholders instead of being paid out as interest to bondholders. The low scores in the range of 0.73 for the Netherlands and 1.30 for the U.K. offer little support for this notion. Because the problem is induced by high leverage we expect that the underinvestment problem is more relevant in the high leverage samples. In France we indeed find significantly different scores of 2.17 and 1.13, indicating that underinvestment matters more in highly levered firms. However, for Germany we find the

\footnotetext{
${ }^{7}$ See Ross, 1977 and Leland and Pyle, 1977.

${ }^{8}$ Focusing on firms intended to issues equity yields comparable results, indicating that the firms in our sample do not actively signal information on their corporate prospects and value through their capital structure policy (results not reported).

${ }^{9}$ We also find for firms that considered to issue foreign debt do so because foreign rates are more favourable (results not tabled). The scores are much higher in the U.S. (2.19), the Netherlands (2.42) and G ermany (2.64), in comparison with the U.K. (1.36) and France (1.38).
} 
inverse difference, which is also significant at the 10\% level. Myers' (1977) model also implies that this underinvestment problem can be mitigated by short term financing. In row (d) of Table 9 we test this hypothesis and the results are in line with our earlier findings, again scores are consistently below 1.00 .

Asset substitution is another agency problem in which shareholder prefer high-risk projects, because they can fully benefit from the upside potential. On the other hand, bondholders have a fixed claim and prefer projects with lower risk. Leland and Toft (1996) model this problem and find short-term debt as a solution. Table 9, row (f) reports low scores, well below 1.00, in each of the five countries. ${ }^{\text {D }}$ The results for the five countries are remarkably similar. By constructing an anti-director index La Porta et al. (1998) show that shareholders have a much larger influence in U.S. and U.K. firms. One would expect shareholder-bondholder problems in countries with high shareholder influence and low creditor rights, i.e. the U.S. In Germany, one would expect the problems to be less relevant. Given these strong institutional differences, it is striking that the theories are not found to be relevant in either of the countries.

\subsubsection{Conflicts between managers and equityholders}

Jensen (1986) notices that managers may have incentives to strive for firm growth by adopting negative NPV projects. Moreover, Jensen and Meckling (1976) argue that managers may work less efficiently, because they are merely partial or no owners of the firm. Through its fixed obligations debt is considered to be a disciplining device, which might mitigate these principle-agent difficulties. However, our results in row (m) of Table 7 imply that the disciplining role of debt is equally unimportant in each of the five countries, where scores never exceed 0.70. Graham and Harvey attribute the U.S. result to two reasons: (1) respondents' bias because managers do not want to admit this behaviour; and (2) unwillingness of managers to discipline themselves through debt. It is noteworthy that the above-mentioned anti-director index of La Porta et al. (1998) again does not induce crosscountry differences.

\subsection{M ultivariate regression analysis}

In the previous analyses we have noted that cross-country differences arise in our results. We also found that a target ratio and leverage influence the respondents' choices. Two important models seem to be relevant, i.e. the pecking order model and the static trade-off model. We will now discuss these models in more detail. Moreover, we estimate whether the choices are driven by cross-country differences or by firm characteristics.

As mentioned before, row (g) of Table 7 demonstrates that financial flexibility is the most important factor that influences the amount of debt in each of the five countries, with scores between 2.59 in the U.S. and 1.84 in France. On the one hand, this seems to be evidence in favour of the pecking-order model, since flexibility increases the possibility to choose between different financing alternatives. On the other hand, Opler et al. (1999) show that

${ }^{10}$ Green (1984) has developed a prominent model in which asset substitution is mitigated by convertible debt issues. We find in unreported analyses that protecting bondholders against unfavourable actions of shareholders and managers is not an important factor in the convertible debt choice, again the results are consistent and are equal or less than 1.00 . 
flexibility may be important for other reasons than the pecking order. In Table 10 we report a regression test in which a dummy for a high score (3 and 4) on flexibility is explained by country dummies. In order to avoid perfect multicollinearity we omit the Netherlands. The results yield no significant country dummies, which is in line with our earlier findings. In Model 2 we add firm characteristics. Interesting is that flexibility is significantly (at the 10\% level) more important in firms with a target debt ratio. This finding contradicts the peckingorder interpretation of this question. A more detailed test of the pecking order is to investigate the relationship between asymmetric information and the desire for flexibility. Graham and Harvey use size and dividends as proxies for information problems, i.e. larger and dividend-paying firms have less asymmetry. Therefore, larger firms and dividend-payers are expected to score lower on flexibility. We find the inverse, as both size and dividends have positive coefficients (the coefficient for dividends is significant at the $1 \%$ level). The result is similar to the uni-variate comparisons in the U.S. where larger firms score (insignificantly) higher and also dividend-payers score higher (significant at the $1 \%$ level). These results corroborate with Graham Harvey's conclusion that the desire for financial flexibility is not driven by the pecking-order theory.

Firms that adopt the static trade-off model do so in two steps. First they decide to set a target capital structure. Then they choose factors that are included in the trade-off for the optimal capital structure. In Table 10 we investigate which factors induce firms to set a target capital structure. Model 1 contains country dummies and shows that French firms are significantly less likely to set a target. After including firm characteristics we find that leverage, size and dividends have a positive impact on the probability of aiming for a target, significant at the $1 \%$ level. In theory, no models exist that predict which firms have a target and which firms do not. ${ }^{2}$ As far as we know, we are the first to document empirically that targets are most likely set by large, highly-levered, dividend-paying firms. Adding the cross-sectional variation in shareholder orientation does not attribute to explaining the target setting dilemma.

Under the static trade-off theory firms trade off tax advantages and bankruptcy costs. We estimate the relations between country dummies plus firm characteristics and these factors. Another set of factors are the agency models, but our summary statistics already revealed that these are of minor importance. Our regression results show that in Germany the tax advantage is less important. However, the next regression in Model 2 illustrates that the result is driven by cross-country differences in firm characteristics. After including additional variables the coefficient for $\mathrm{G}$ ermany looses most of its significance. O bviously, the presence of a target significantly increases the probability that tax issues are important. Also large firms appear to find tax advantages more relevant. Bankruptcy costs are the cost of leverage in the static trade-off and measured as the probability that a firm considers the costs of bankruptcy (Table 7, row (b)) or the likelihood (Table 7, row (h)) important. Again we find that these

${ }^{11}$ Brav et al. (2003) argue that the levels of dividends are nearly untouchable. This implies that paying dividends reduces the flexibility of firms, which explains the positive relation we report between the importance of flexibility and dividends.

${ }^{12}$ Additional regression analysis shows that the relationship between firm size and the probability of aiming at a capital structure target is significantly stronger for our European firms than among the U.S. firms of G raham and Harvey (2001). 
costs are less relevant in Germany, but this difference reduces after extending the estimation model. As expected, we also find a significantly positive effect for firms with a target.

The regression results in Table 10 also include a dummy variable for shareholderorientation, which is insignificant in each of the four models. This contrasts with the capital budgeting results. Although both decisions have implications for shareholder wealth, the link is much more direct in capital budgeting.

A comparison between the variables for countries and the firm characteristics show that countries matter, but tell only part of the story. For flexibility, countries have no effect and for tax advantages the single significant coefficient becomes insignificant once other variables are included. Judging from the $\mathrm{R}^{2} \mathrm{~s}$, the country-effects explain much less of the variation, in comparison with the other firm-level characteristics.

In Europe we document the following conclusions regarding capital structure practices. We find moderate support for the static trade-off theory, which predicts that firms have a target debt ratio, based on tax and bankruptcy considerations. In the U.S. the strongest evidence is found, both for the existence of targets and for the role of corporate taxes. The pecking order theory is rejected in each of the countries. However, the result of this theory, the desire for financial flexibility, is an important consideration in all countries. But, because asymmetric information problems do not drive this desire, pecking order theory cannot explain this result. The relevance of agency problems and the benefits of signaling in capital structure choice are caused by divergent interests and the ability of shareholders and creditors to monitor each other and the management. Although recent studies suggest strong differences between the countries, we do not find convincing evidence of agency problems, signaling, or a role of capital structure in control contests in either country. This is a striking result because current theoretical and empirical literature largely focuses on these issues.

We conclude that the static trade-off theory faces moderate confirmation. Financial flexibility is important, but not driven by the pecking order theory. Several practical considerations are highly relevant. Contrary to the institutional variations we document strong resemblances between the five very different countries when comparing capital structure policies. Differences emerge in the relevance of the public financial markets. In the U.S. and U.K., and to a lesser extent in the Netherlands, firms use the stock prices and interest rates in their decisions, while in Germany and France internal considerations appear to be are more relevant.

\section{Conclusions}

In this paper we examine the practice of corporate finance in four European countries: the U.K., the Netherlands, Germany and France and compare these practices with previous results of Graham and Harvey (2001) for U.S. firms. O ur results offer a rare opportunity to directly investigate the use and adoption of academic concepts by professionals active outside the United States. The contribution of this paper therefore is multiple. First professionals can learn by observing the practice of their European colleagues. Second our survey reveals where theoretical concepts fall short in tackling practical dilemmas, and thereby this paper can inspire academics in extending and refining existing notions. Third, we analyze the extend to which existing insights that originate from numerous U.S. studies hold outside the United 
States, and reveal what factors are really driving the practice of financial management in firms. Several studies have stressed the differences between institutional settings, when comparing the United States and Europe. These studies claim that these institutional differences determine how firm manage their capital and therefore create an international variation in corporate finance practice. We have tested whether European firms and U.S. firms are different, and which characteristics explain corporate policies regarding capital budgeting, cost of capital and capital structure.

We observe a remarkable cross-national pattern with respect to corporate governance. Firms in the U.K. and the Netherlands are consciously thriving at maximizing their shareholder's wealth, while German and French firms attach a low priority to this corporate goal. Regarding the corporate finance practices we find remarkably little difference across countries. With respect to capital budgeting techniques we discover a strong preference for the simple payback criterion among our European firms. Although this preference is stronger in Europe it does not differ significantly from capital budgeting policies of U.S. firms. We find that this preference for payback criteria is consistently stronger among small firms and among firms, which are less oriented towards shareholder wealth maximization. Of the firms that do discount their cash-flow forecast, most CFOs responded to be using the CAPM when computing their cost of equity capital. This preference of CAPM over more intuitive alternatives is comparable to how U.S. firms compute the cost of capital. The use of CAPM tends rise with firm size, CEO tenure, and the importance of shareholder wealth maximization, while the educational background of the CEO appears to be irrelevant. Finally regarding capital structure policy we find surprisingly little continental differences. Although recent studies by La Porta et al. $(1997,1998)$ and Rajan and Zingales (2003a, 2003b) have illustrated the institutional variation that is present within our international sample. These differences seem to have little affect on firm's capital structure practice. Financial flexibility is reported to be the most important factor, when determining the proper of amount of corporate debt. On the other hand this urge for flexibility is not driven by the pecking order theory. Furthermore, we find no evidence for agency theories, signaling, or a role of capital structure in control contest.

Alike Graham and Harvey (2001) we document fundamental differences between large and small firms when analyzing corporate finance practices. $O$ ur results show that large firms are likely to use more sophisticated techniques when it comes to evaluating risky projects. In all samples we find that large firms are more likely to use NPV criteria and the CAPM for calculating the proper discount rate. Moreover, our results show that large firms are apt to utilizing more sophisticated, risk-matched discount rates instead of a standard firm cost of capital. This consistent difference in corporate finance practice along the size dimension is an intriguing result, which might help us to understand the well-documented size anomalies in the asset pricing literature.

In both the U.S. and European markets professionals tend to adopt and neglect the same theoretical models and theories when managing their finances. The gap between science and practice appears to be rather constant across borders and although institutional difference are large and significant, they do not seem to dominate the way firms are run financially. 


\section{References}

Bancel, F., Mittoo,U.R., 2003. The determinants of capital structure choice: a survey of European firms, unpublished working paper.

Billingsley, R.S., Smith D.M., 1996. Why do firms issue convertible debt? Financial Mangement 25, 93-99.

Brav, A., Graham, J.R., Harvey, C.R., Michaely, R., 2003. Payout policy in the 21 $1^{\text {st }}$ century, unpublished working paper, Duke University.

Brealey, R.A., Myers, S.C., 2003. Principles of corporate finance. 7th Edition. McG raw-Hill, New York.

De Bondt, G .J., 1998. Financial structure: theories and stylized facts for six EU countries. De Economist 146, 271-301.

Chew, D., 1997. Studies in International Corporate Finance and Governance Systems: A Comparison of the U.S., Japan, and Europe, 0 xford University Press.

Fama, E.F., French, F.R., 1992. The cross-section of expected stock returns. Journal of Finance 47, 427-465.

Fischer, E.O., Heinkel, R., Zechner, J., 1989. Dynamic capital structure choice: theory and tests. Journal of Finance 44, 19-40.

Flannery, M.J., 1986. Asymmetric information and risky debt maturity choice. Journal of Finance 41, 19-37.

Graham, J.R., Harvey, C.R., 2001. The theory and practice of corporate finance: evidence from the field. Journal of Financial Economics 61, 187-243

Green, R., 1984. Investment incentives debt and warrants. Journal of Financial Economics $13,115-136$.

Jegadeesh, N., Titman, S., 1993. Returns to buying winners and selling losers: implications for stock market efficiency. Journal of Finance 48, 65-91.

Jensen, M.C., 1986. Agency costs of free cash flow, corporate finance, and take- overs, American Economic Review 76, 323-329.

Jensen, M.C., Meckling, W.H., 1976. Theory of the firm: managerial behavior, agency costs and ownership structure, Journal of Financial Economics 3, 305-360.

La Porta, R., Lopez-de-Silanes, F., Shleifer, A., Vishny, R.W., 1998. Law and finance, Journal of Political Economy 106, 1113-1155.

La Porta, R., Lopez-de-Silanes, F., Shleifer, A., Vishny, R.W. 1997. Legal determinants of external finance. Journal of Finance 52, 1131-1150.

Leland, H.E., Pyle,D.H., 1977. Informational asymmetries, financial structure, and financial intermediation. Journal of Finance 32, 371-387.

Leland, H.E., Toft, K.B., 1996. O ptimal capital structure, endogenous bankruptcy, and the term structure of credit spreads. Journal of Finance 51, 987-1019.

Lintner, J., 1956. Distributions of incomes of corporations among dividends, retained earnings, and taxes. American Economic Review, 97-113.

Myers, S.C., 1977. D eterminants of corporate borrowing. Journal of Financial Economics 5, 147-175.

Myers, S.C., Majluf, N., 1984. Corporate financing and investment decisions when firms have information that investors do not have. Journal of Financial Economics 13, 3-46.

Moore, J.S., Reichert, A.K., 1983. An analysis of the financial management techniques currently employed by large U.S. corporations. Journal of Business Finance and Accounting 10, 623-645. 
Opler, T.C., Pinkowitz, L., Stulz, R., Williamson, R., 1999. The determinants and implications of corporate cash holdings. Journal of Financial Economics 52, 3-46.

Rajan, R.G., Zingales, L. 1995. What do we know about capital structure? Some evidence from international data. Journal of Finance 50, 1421-1460.

Rajan, R.G., Zingales, L. 2003a. Banks and markets: the changing character of European Finance. European Central Bank $2^{\text {nd }}$ Annual Conference Volume 2003, 124-167.

Rajan, R.G., Zingales, L. 2003b. The great reversals: the politics of financial development in the twentieth century. Journal of Financial Economics 69, 5-50.

Ross, S.A., 1977. The determination of financial structure: the incentive signaling approach. Bell Journal of Economics 8, 1-32.

Trahan, E.A., Gitman, L.J., 1995. Bridging the theory-practice gap in corporate financ: a survey of chief financial officers. Q uarterly Review of Economics and Finance 35, 73-87.

Welch, I. 2004. Capital structure and stock returns. Journal of Political Economy, forthcoming. 
Figure 1: Corporate goals and important stakeholders

These tables summarize the national average responses to the questions: "W hich goals are important for your firm?" and "W hich stak eholders are important for your firm?"

\section{A: Corporate Goals (0, not important, 4 , very important)}

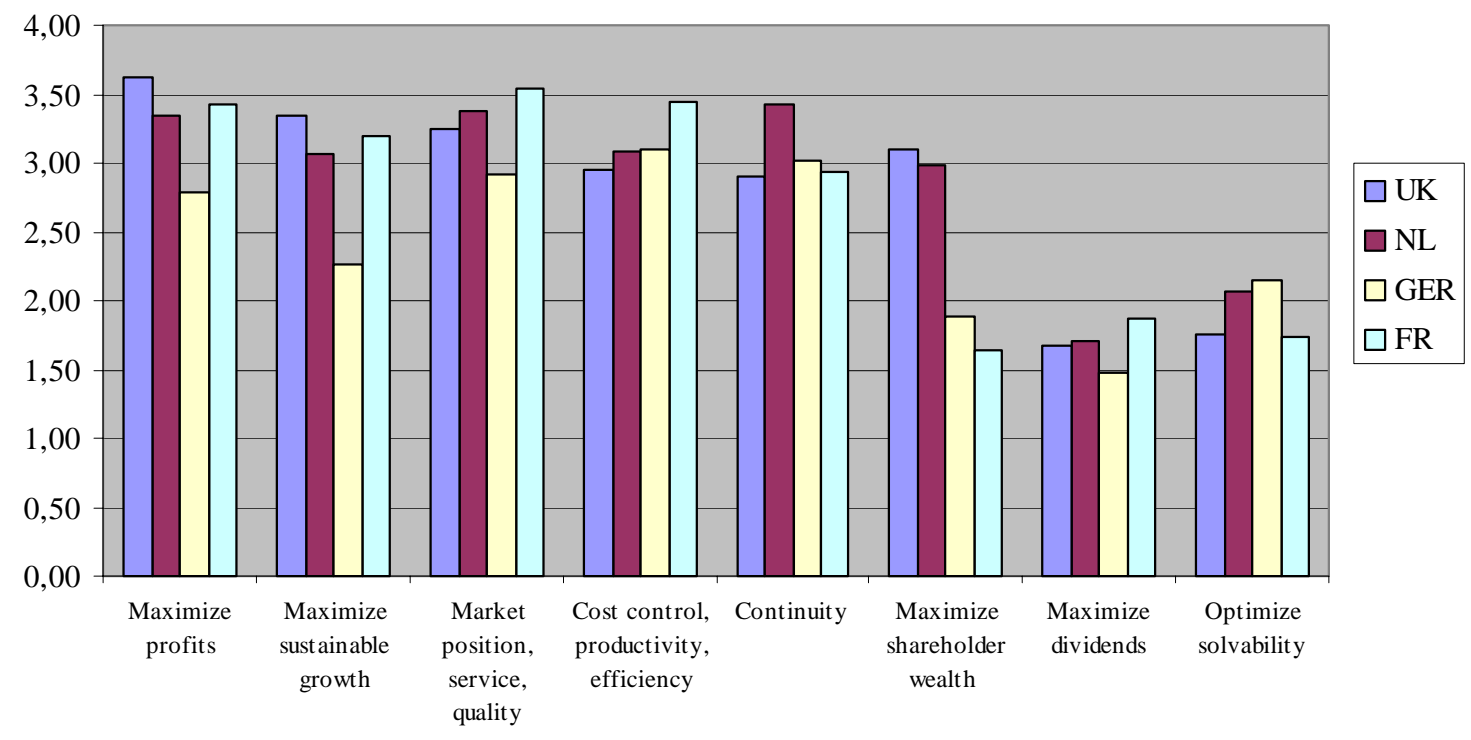

\section{B: Importance of stakeholders (0, not important, 4, very important)}

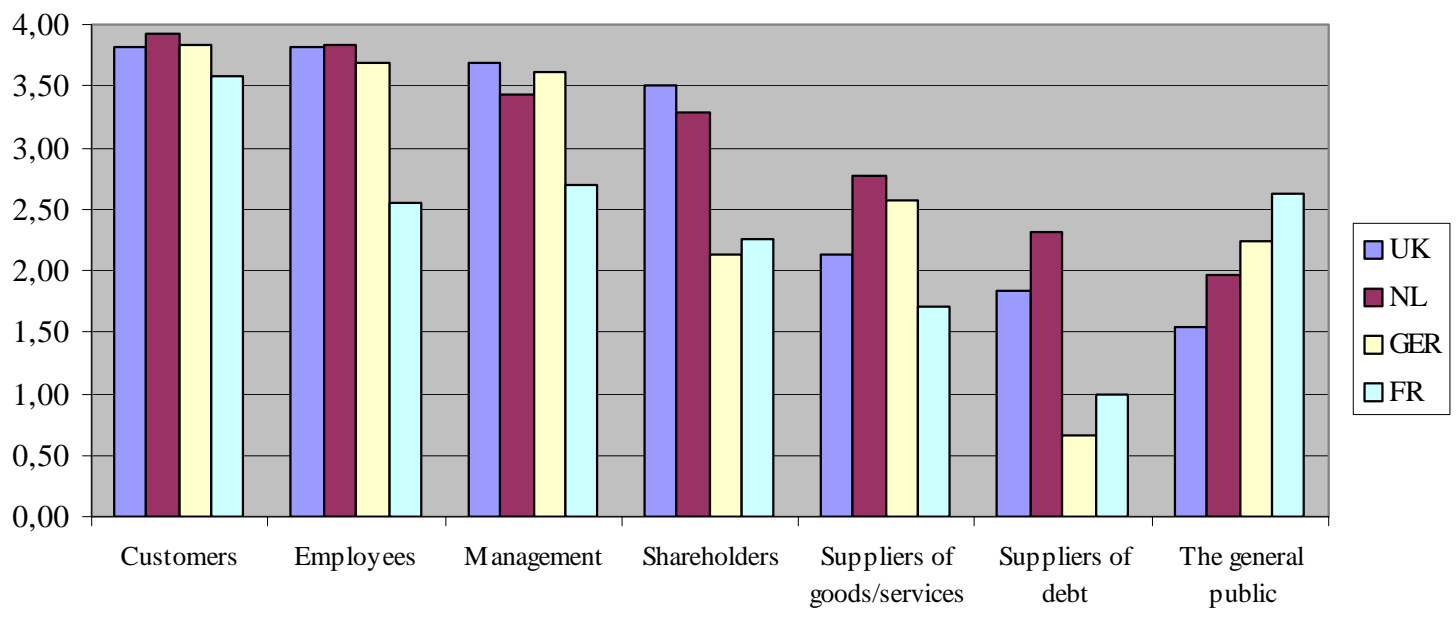


Figure 2: Firm characteristics

\section{A: Sales (million \$)}

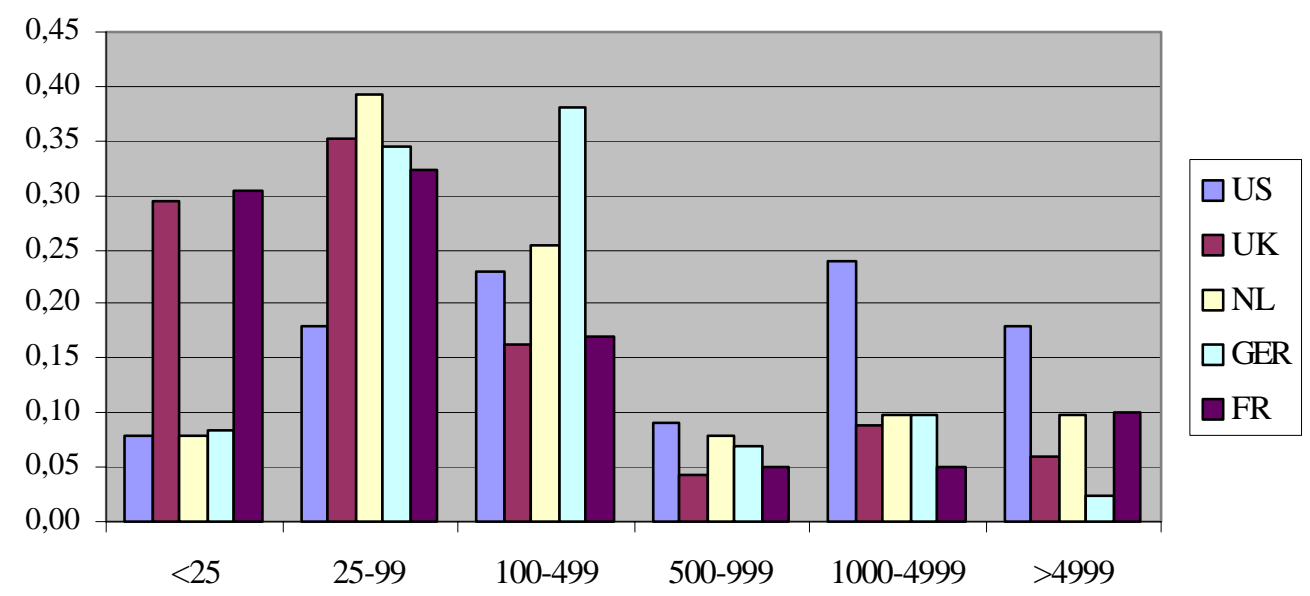

B: Foreign sales (\% of total)

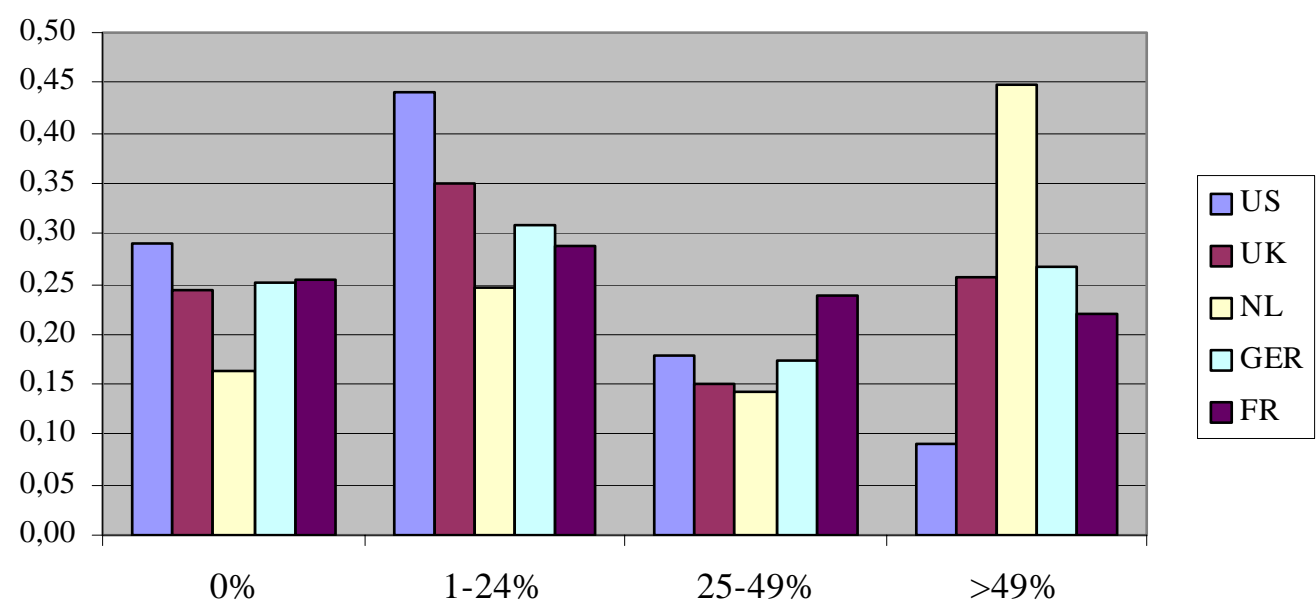

\section{C: Industry}

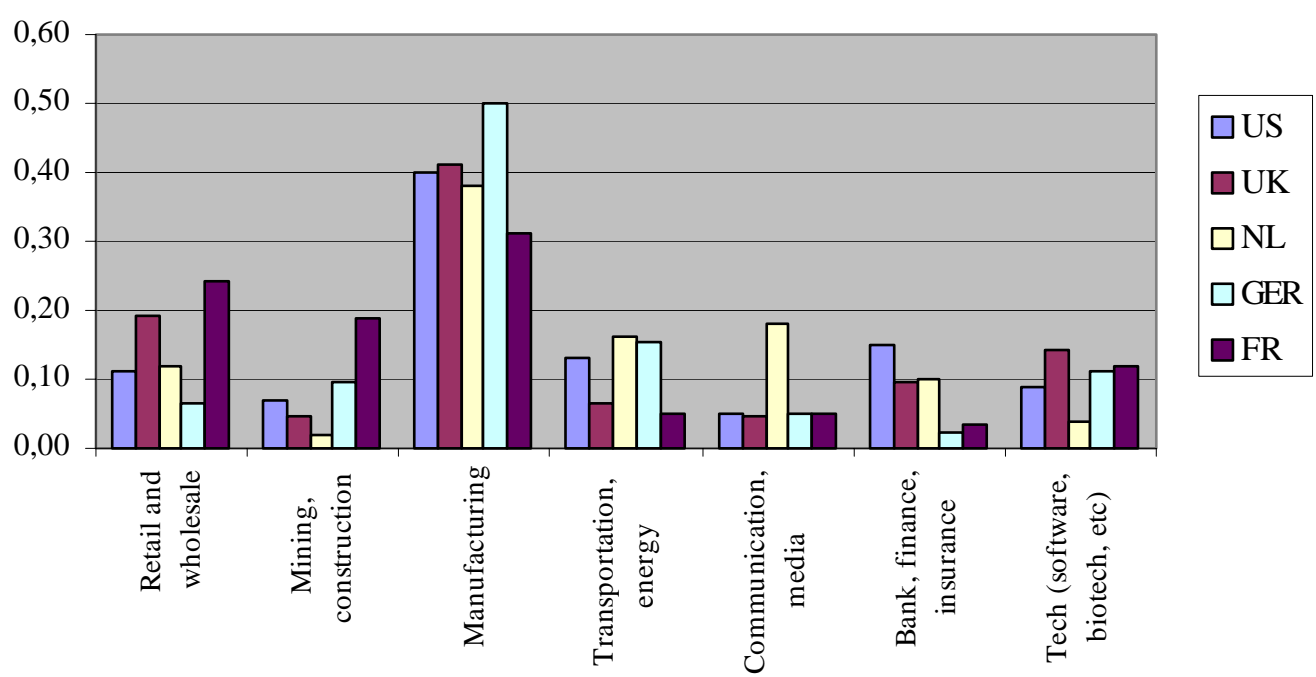


Figure 2: Firm characteristics (continued)

\section{D: Price/earnings ratio}

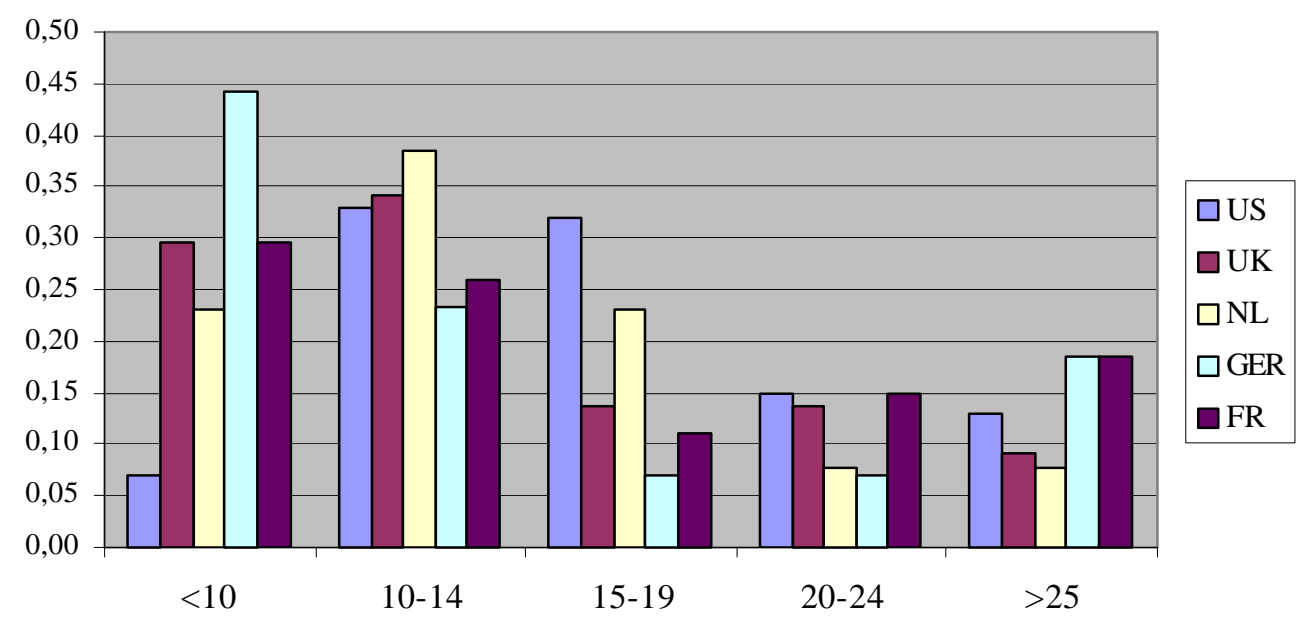

E: Longterm debt ratio (\%)

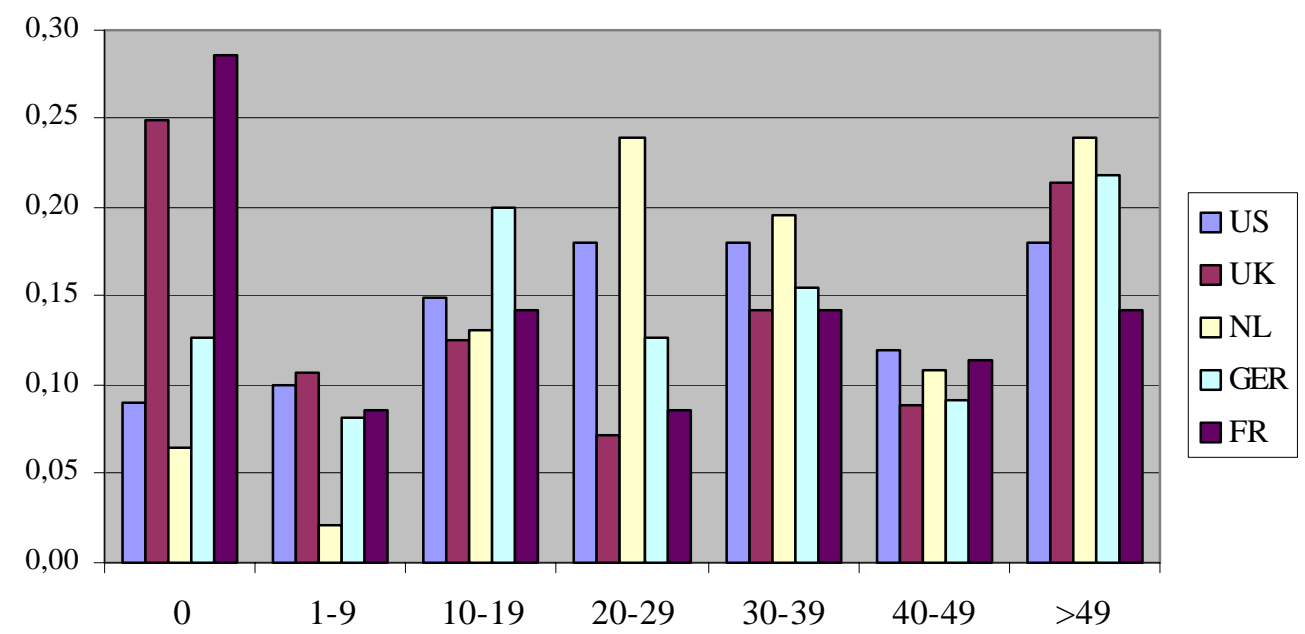

F: Target debt ratio

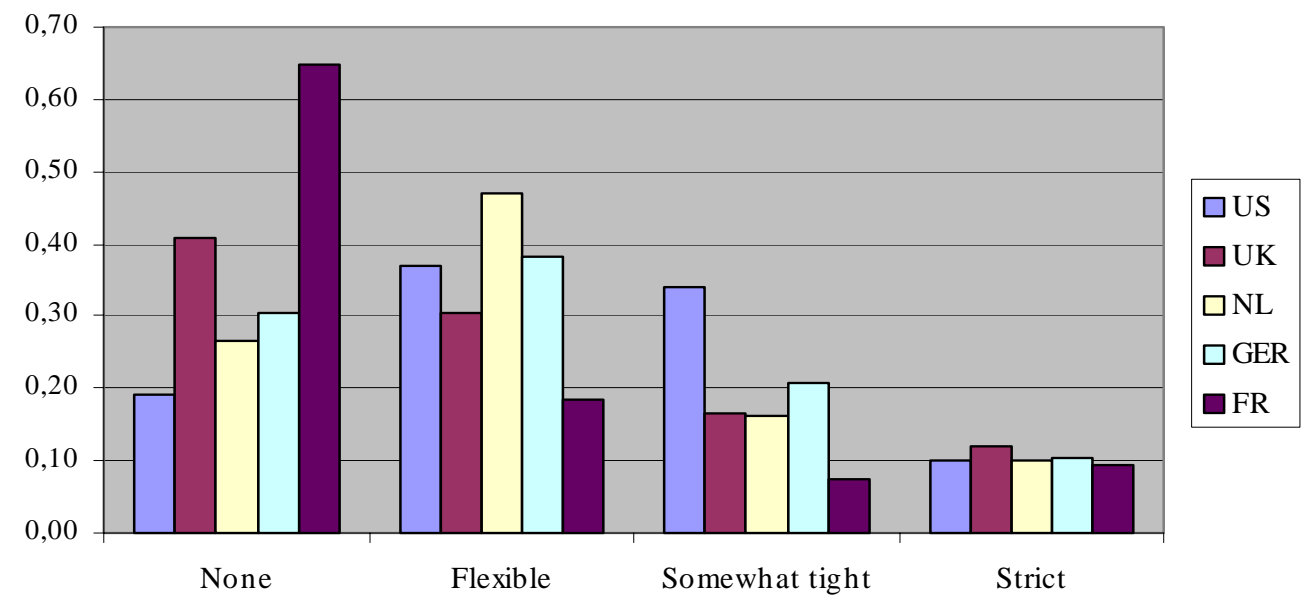


Figure 2: Firm characteristics (continued)

\section{G: Percent that seriously considered issuing...}

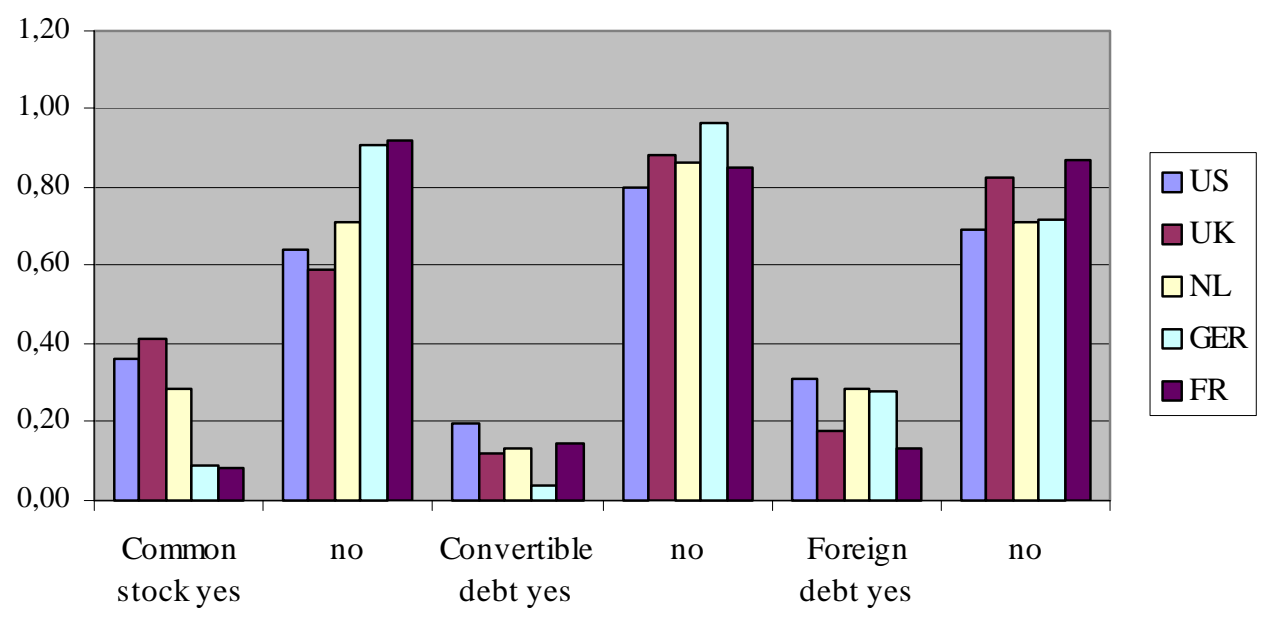

H: CEO Age (years)

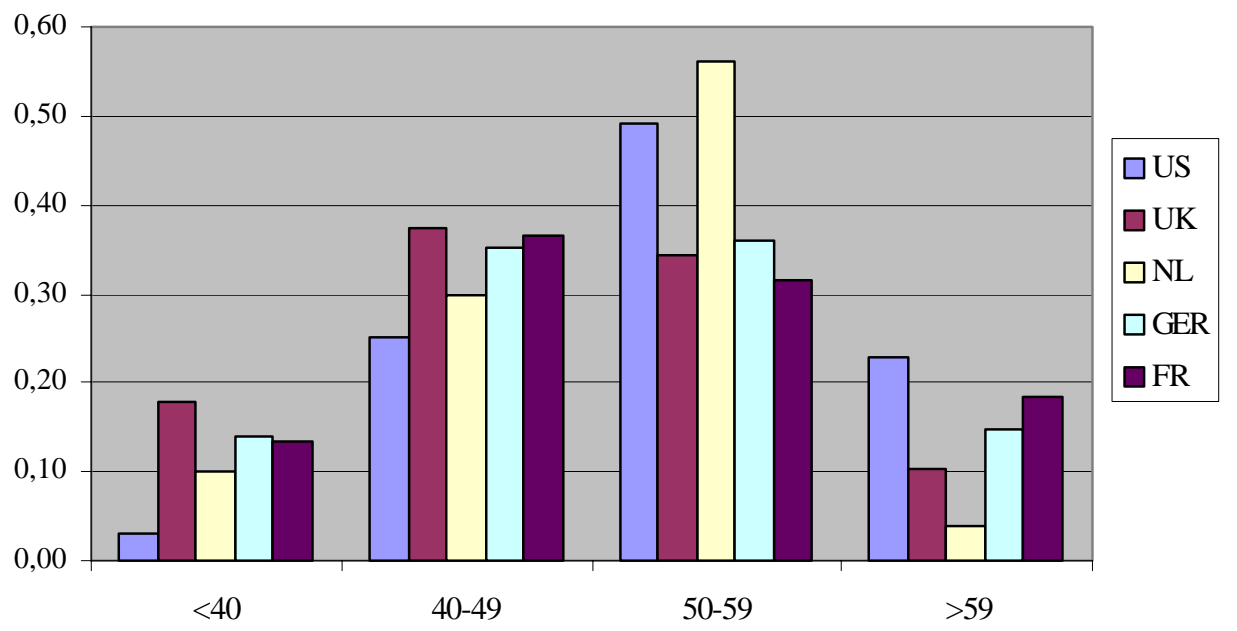

I: CEO Tenure (years)

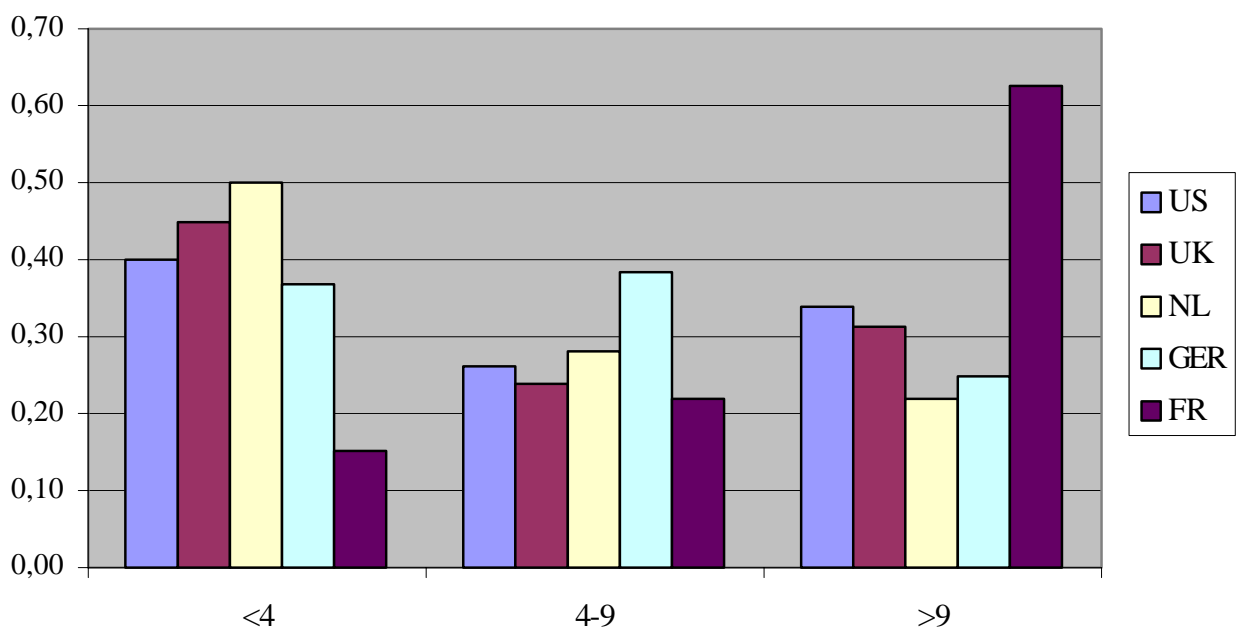


Figure 2: Firm characteristics (continued)

\section{J: CEO Education}

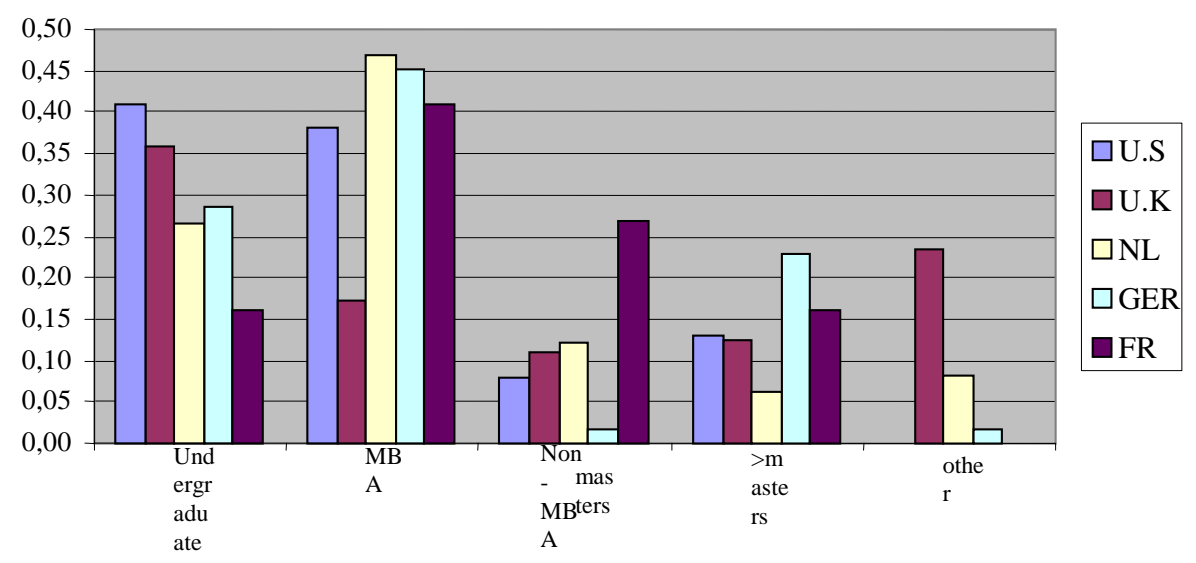

K: Executive stock ownership (\%)

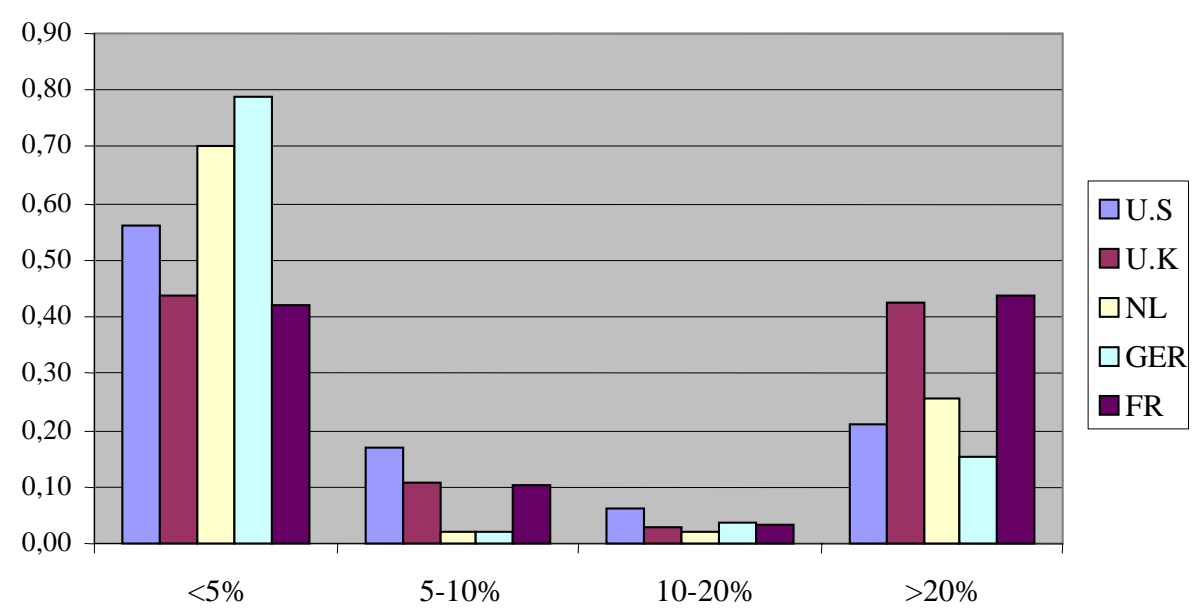


Table 1: Summary statistsics and cross comelations

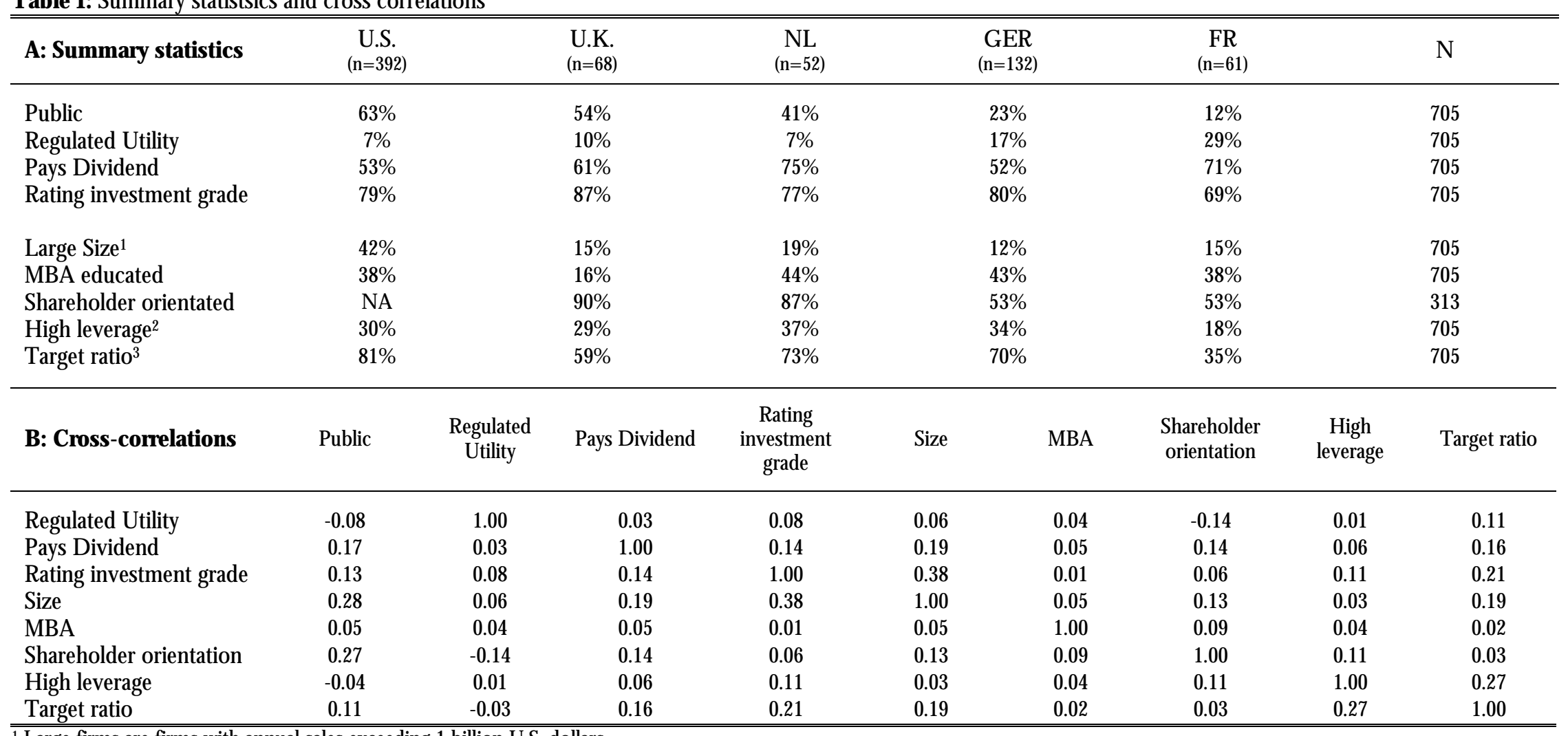

${ }^{1}$ Large firms are firms with annual sales exoeeding 1 billion U.S. dollars.

2 We classify firms with long-term debt ratios exceeding $30 \%$ as high levered firms.

${ }^{3}$ Firms, which anounced to have strict or even tight target debt ratios are classified as 'target ratio'. 
Table 2

Survey responses to thequestion "Howfiequently dbes your firmuse thefdlowingteehniques when deiding which prieets or acquisitions to pursue?"

\begin{tabular}{|c|c|c|c|c|c|c|c|c|c|c|c|c|c|c|c|c|c|c|c|}
\hline & & \multicolumn{6}{|c|}{ U.S. } & \multicolumn{6}{|c|}{ U.K. } & \multicolumn{6}{|c|}{ Netherlands } \\
\hline & & \multirow{2}{*}{$\begin{array}{c}\% \text { always } \\
\text { or almost } \\
\text { always }\end{array}$} & \multirow{2}{*}{ Mean } & \multicolumn{2}{|c|}{ Size } & \multicolumn{2}{|c|}{ CEO MBA } & \multirow{2}{*}{$\begin{array}{c}\% \text { always } \\
\text { or almost } \\
\text { always }\end{array}$} & \multirow[b]{2}{*}{ Mean } & \multicolumn{2}{|c|}{ Size } & \multicolumn{2}{|c|}{ CEO MBA } & \multirow{2}{*}{$\begin{array}{c}\% \text { always } \\
\text { or almost } \\
\text { always }\end{array}$} & \multirow[b]{2}{*}{ Mean } & \multicolumn{2}{|c|}{ Size } & \multicolumn{2}{|c|}{ CEO MBA } \\
\hline & & & & Small & Large & Yes & No & & & Small & Large & Yes & No & & & Small & Large & Yes & No \\
\hline (b) & Intemal rate of retum & 75.61 & 3.09 & 2.87 & $3.41^{* 1 *}$ & 3.17 & 3.03 & 53.13 & 2.31 & 3.33 & $2.15^{\text {+10k }}$ & 1.70 & 2.50 & 56.00 & 2.36 & 2.25 & 2.80 & 2.73 & $2.07 *$ \\
\hline (a) & Net present value & 74.93 & 3.08 & 2.83 & $3.42^{* 2 *}$ & 3.17 & $3.00^{*}$ & 46.97 & 2.32 & 2.12 & $3.56^{101 *}$ & 2.18 & 2.45 & 70.00 & 2.76 & 2.53 & $3.70^{\text {redek }}$ & 2.86 & 2.68 \\
\hline (f) & Payback period & 56.74 & 2.53 & 2.72 & $2.25^{10 \%}$ & 248 & 2.55 & 69.23 & 2.77 & 2.77 & 2.75 & 2.73 & 2.74 & 64.71 & 2.53 & 2.56 & 2.40 & 2.86 & 2.28 \\
\hline (c) & Hurdle rate & 56.94 & 2.48 & 2.13 & $2.95^{1+2 *}$ & 2.57 & 2.42 & 26.98 & 1.35 & 1.07 & $3.00^{1+10}$ & 0.80 & 1.49 & 41.67 & 1.98 & 1.74 & $2.90^{*}$ & 2.36 & 1.65 \\
\hline (j) & Sensitivity analysis & 51.54 & 2.31 & 2.13 & $2.56^{\text {*19k }}$ & 2.41 & 2.25 & 42.86 & 2.21 & 2.02 & $3.50^{1+10 k}$ & 1.60 & 2.35 & 36.73 & 1.84 & 1.74 & 2.20 & 1.91 & 1.78 \\
\hline (d) & Eamings multiple approach & 38.92 & 1.89 & 1.89 & $2.01 *$ & 1.98 & 1.86 & 39.06 & 1.81 & 1.78 & 2.00 & 1.90 & 1.90 & 26.53 & 1.61 & 1.56 & 1.80 & 1.82 & 1.44 \\
\hline (g) & Discounted payback period & 29.45 & 1.56 & 1.56 & 1.55 & 1.68 & 1.49 & 25.40 & 1.49 & 1.56 & 1.00 & 2.20 & $1.31^{*}$ & 25.00 & 1.25 & 1.32 & 1.00 & 1.27 & 1.23 \\
\hline (l) & $\begin{array}{l}\text { We incorporate the "real options" of } \\
\text { a project when evaluating it }\end{array}$ & 26.56 & 1.47 & 1.47 & 1.57 & 1.49 & 1.39 & 29.03 & 1.65 & 1.67 & 1.50 & 2.09 & 1.49 & 34.69 & 1.49 & 1.62 & 1.00 & 1.57 & 1.43 \\
\hline (i) & Acoounting rate of retum & 20.29 & 1.34 & 1.34 & 1.25 & 1.42 & 1.29 & 38.10 & 1.79 & 1.82 & 1.63 & 1.30 & 1.90 & 25.00 & 1.40 & 1.45 & 1.20 & 1.27 & 1.50 \\
\hline (k) & Value at risk & 13.66 & 0.95 & 0.95 & $1.22^{100 *}$ & 0.99 & 0.88 & 14.52 & 0.85 & 0.72 & $1.75^{*}$ & 0.80 & 0.94 & 4.26 & 0.51 & 0.47 & 0.67 & 0.71 & 0.35 \\
\hline (e) & Adjusted present value & 10.78 & 0.85 & 0.85 & $0.72^{*}$ & 0.74 & $0.91^{*}$ & 14.06 & 0.78 & 0.71 & 1.22 & 1.20 & 0.76 & 8.16 & 0.78 & 0.74 & 0.90 & 0.73 & 0.81 \\
\hline (h) & Profitability index & 11.87 & 0.85 & 0.83 & 0.75 & 0.83 & 0.85 & 15.87 & 1.00 & 1.15 & $0.00^{\text {rexk }}$ & 1.60 & 0.92 & 8.16 & 0.78 & 0.82 & 0.60 & 0.77 & 0.78 \\
\hline
\end{tabular}


Table 2- continued

Survey responses to thequestion "Howfiequently dbes your fim usethefdlowing teehniques when deiding which priets or acquisitions to pursue?"

\begin{tabular}{|c|c|c|c|c|c|c|c|c|c|c|c|c|c|}
\hline & & \multicolumn{6}{|c|}{ Gemmany } & \multicolumn{6}{|c|}{ France } \\
\hline & & \multirow{2}{*}{$\begin{array}{c}\text { \% always } \\
\text { or almost } \\
\text { always }\end{array}$} & \multirow[b]{2}{*}{ Mean } & \multicolumn{2}{|c|}{ Size } & \multicolumn{2}{|c|}{ CEO MBA } & \multirow{2}{*}{$\begin{array}{c}\% \text { always } \\
\text { or almost } \\
\text { always }\end{array}$} & \multirow[b]{2}{*}{ Mean } & \multicolumn{2}{|c|}{ Size } & \multicolumn{2}{|c|}{ CEO MBA } \\
\hline & & & & Small & Large & Yes & No & & & Small & Large & Yes & No \\
\hline (b) & Intemal rate of retum & 42.15 & 2.15 & 2.04 & $3.08^{12 k}$ & 2.40 & $1.97 *$ & 44.07 & 2.27 & 2.18 & 2.88 & 2.82 & $1.95^{* *}$ \\
\hline & Net present value & 47.58 & 2.26 & 208 & $3.64^{* 1 *}$ & 2.70 & $1.93^{\text {*at }}$ & 35.09 & 1.86 & 1.63 & $3.25^{* 10 *}$ & 2.30 & 1.62 \\
\hline (f) & Payback period & 50.00 & 2.29 & 2.31 & 2.08 & 2.40 & 2.21 & 50.88 & 2.46 & 2.51 & 2.13 & 2.52 & 2.42 \\
\hline & Hurdle rate & 28.81 & 1.61 & 1.52 & 2.31 & 1.59 & 1.62 & 3.85 & 0.73 & 0.80 & $0.17^{10 k}$ & 0.76 & 0.71 \\
\hline (j) & Sensitivity analysis & 28.07 & 1.65 & 1.58 & 2.15 & 2.04 & 1.37 ade & 10.42 & 0.79 & 0.85 & 0.43 & 0.50 & 0.97 \\
\hline & Eamings multiple approach & 20.51 & 1.25 & 1.18 & 1.77 & 1.47 & 1.09 & 33.33 & 1.70 & 1.73 & 1.50 & 1.84 & 1.63 \\
\hline & Discounted payback period & 30.51 & 1.59 & 1.50 & $2.31^{*}$ & 1.57 & 1.61 & 11.32 & 0.87 & 0.91 & 0.57 & 1.11 & 0.74 \\
\hline (l) & $\begin{array}{l}\text { We inoorporate the "real options" of } \\
\text { a project when evaluating it }\end{array}$ & 44.04 & 2.24 & 2.28 & 1.92 & 2.22 & 2.25 & 53.06 & 2.20 & 2.27 & 1.88 & 2.05 & 2.30 \\
\hline (i) & Acoounting rate of returm & 32.17 & 1.63 & 1.76 & $0.62^{* 1 *}$ & 1.46 & 1.76 & 16.07 & 1.11 & 1.16 & 0.71 & 1.15 & 1.08 \\
\hline & Value at risk & 23.68 & 1.45 & 1.36 & $2.15^{* *}$ & 1.73 & $1.24^{*}$ & 29.79 & 1.68 & 1.66 & 1.83 & 2.00 & 1.50 \\
\hline & Adjusted present value & 7.83 & 0.71 & 0.63 & $1.38^{*}$ & 0.96 & $0.54^{* *}$ & 14.55 & 1.11 & 1.12 & 1.00 & 1.53 & $0.89^{*}$ \\
\hline & Profitability index & 16.07 & 1.04 & 1.00 & 1.31 & 0.98 & 1.08 & 37.74 & 1.64 & 1.63 & 1.71 & 2.00 & 1.46 \\
\hline
\end{tabular}


Table 3

Survey responses to thequestion "Does your fimmestimate thecost of equity capital? If "yes", howdbyou datemineyour fimis cest of equity capital?

\begin{tabular}{|c|c|c|c|c|c|c|c|c|c|c|}
\hline & \multicolumn{2}{|c|}{ U.S. } & \multicolumn{2}{|c|}{ U.K. } & \multicolumn{2}{|c|}{ Netherlands } & \multicolumn{2}{|c|}{ Germany } & \multicolumn{2}{|c|}{ France } \\
\hline & $\begin{array}{c}\text { \% always } \\
\text { or almost } \\
\text { always }\end{array}$ & Mean & $\begin{array}{c}\% \text { always } \\
\text { or almost } \\
\text { always }\end{array}$ & Mean & $\begin{array}{c}\% \text { always } \\
\text { or almost } \\
\text { always }\end{array}$ & Mean & $\begin{array}{c}\% \text { always } \\
\text { or almost } \\
\text { always }\end{array}$ & Mean & $\begin{array}{c}\% \text { always } \\
\text { or almost } \\
\text { always }\end{array}$ & Mean \\
\hline (b) Using the Capital Asset Pricing Model (CAPM, the beta approach) & 73.49 & 2.92 & 47.06 & 2.06 & 55.56 & 2.37 & 33.96 & 1.36 & 45.16 & 1.90 \\
\hline (a) With average historical retums on common stock & 39.41 & 1.72 & 31.25 & 1.47 & 30.77 & 1.42 & 18.00 & 1.06 & 27.27 & 1.30 \\
\hline (c) Using the CAPM but including some extra "isk factors" & 34.29 & 1.56 & 27.27 & 1.45 & 15.38 & 1.08 & 16.07 & 0.89 & 30.30 & 1.39 \\
\hline (f) Back out from discounted dividend/ eamings model, e.g: price = div./ (oost of cap. growth) & 15.74 & 0.91 & 10.00 & 0.73 & 10.71 & 0.79 & 10.42 & 0.58 & 10.34 & 0.69 \\
\hline (d) Whatever our investors tell us they require & 13.93 & 0.86 & 18.75 & 1.19 & 44.83 & 1.86 & 39.22 & 1.98 & 34.38 & 1.66 \\
\hline (e) By regulatory decisions & 7.04 & 0.44 & 16.13 & 0.94 & 3.70 & 0.33 & 0.00 & 0.27 & 16.13 & 0.87 \\
\hline
\end{tabular}


Table 4

Survey responses to thequestion "When valuinga priet, dbyou adjust either thediscount rateor cash flous for thefdloningnisk factars?" Perentageof respandents dhoosingeadh categry is repated

\begin{tabular}{|c|c|c|c|c|c|c|c|c|c|c|c|c|c|}
\hline & & \multicolumn{4}{|c|}{ U.S. } & \multicolumn{4}{|c|}{ U.K. } & \multicolumn{4}{|c|}{ Netherlands } \\
\hline & & $\begin{array}{l}\text { Disc. } \\
\text { rate }\end{array}$ & $\begin{array}{l}\text { Cash } \\
\text { flow }\end{array}$ & Both & Neither & $\begin{array}{l}\text { Disc. } \\
\text { rate }\end{array}$ & $\begin{array}{l}\text { Cash } \\
\text { flow }\end{array}$ & Both & Neither & $\begin{array}{l}\text { Disc. } \\
\text { rate }\end{array}$ & $\begin{array}{l}\text { Cash } \\
\text { flow }\end{array}$ & Both & Neither \\
\hline (b) & $\begin{array}{l}\text { Interest rate risk (change in general level of } \\
\text { interest rates) }\end{array}$ & 15.30 & 8.78 & 24.65 & 51.27 & 20.97 & 27.42 & 27.42 & 24.19 & 20.41 & 8.16 & 20.41 & 51.02 \\
\hline (f) & Foreign exchange risk & 10.80 & 15.34 & 18.75 & 55.11 & 12.50 & 32.81 & 17.19 & 37.50 & 6.00 & 26.00 & 18.00 & 50.00 \\
\hline (d) & GDP or business cycle risk & 6.84 & 18.80 & 18.80 & 55.56 & 16.13 & 24.19 & 8.06 & 51.61 & 8.33 & 6.25 & 10.42 & 75.00 \\
\hline (a) & Risk of unexpected inflation & 11.90 & 14.45 & 11.90 & 61.76 & 17.74 & 25.81 & 12.90 & 43.55 & 8.00 & 12.00 & 16.00 & 64.00 \\
\hline (h) & Size (small firms being riskier) & 14.57 & 6.00 & 13.43 & 66.00 & 21.88 & 12.50 & 7.81 & 57.81 & 17.02 & 14.89 & 14.89 & 53.19 \\
\hline (e) & Commodity price risk & 2.86 & 18.86 & 10.86 & 67.43 & 19.05 & 19.05 & 7.94 & 53.97 & 2.13 & 19.15 & 10.64 & 68.09 \\
\hline (c) & $\begin{array}{l}\text { Term structure risk (change in the long-term vs. } \\
\text { short-term interest rate) }\end{array}$ & 8.57 & 3.71 & 12.57 & 75.14 & 17.19 & 17.19 & 12.50 & 53.13 & 10.64 & 0.00 & 10.64 & 78.72 \\
\hline (g) & Distress risk (probability of banknuptcy) & 7.41 & 6.27 & 4.84 & 81.48 & 14.52 & 9.68 & 6.45 & 69.35 & 14.58 & 4.17 & 8.33 & 72.92 \\
\hline (i) & $\begin{array}{l}\text { "Market-to-book" ratio (ratio of market value of } \\
\text { fim to book value of assets) }\end{array}$ & 3.98 & 1.99 & 7.10 & 86.93 & 17.74 & 9.68 & 4.84 & 67.74 & 4.26 & 2.13 & 19.15 & 74.47 \\
\hline (j) & Momentum (recent stock price performance) & 3.43 & 2.86 & 4.86 & 88.86 & 16.95 & 5.08 & 6.78 & 71.19 & 4.35 & 0.00 & 8.70 & 86.96 \\
\hline
\end{tabular}

\begin{tabular}{|c|c|c|c|c|c|c|c|c|c|}
\hline & & \multicolumn{4}{|c|}{ Gemmany } & \multicolumn{4}{|c|}{ France } \\
\hline & & $\begin{array}{l}\text { Disc. } \\
\text { rate }\end{array}$ & $\begin{array}{l}\text { Cash } \\
\text { flow }\end{array}$ & Both & Neither & $\begin{array}{l}\text { Disc. } \\
\text { rate }\end{array}$ & $\begin{array}{l}\text { Cash } \\
\text { flow }\end{array}$ & Both & Neither \\
\hline (b) & $\begin{array}{l}\text { Interest rate risk (change in general level of } \\
\text { interest rates) }\end{array}$ & 26.72 & 1466 & 22.41 & 36.21 & 23.21 & 26.79 & 21.43 & 28.57 \\
\hline (f) & Foreign exchange risk & 13.27 & 19.47 & 18.58 & 48.67 & 16.36 & 20.00 & 5.45 & 58.18 \\
\hline (d) & GDP or business cycle risk & 6.19 & 9.73 & 11.50 & 72.57 & 15.79 & 22.81 & 12.28 & 49.12 \\
\hline (a) & Risk of unexpected inflation & 18.80 & 9.40 & 9.40 & 62.39 & 17.54 & 24.56 & 26.32 & 31.58 \\
\hline (h) & Size (small firms being niskier) & 9.91 & 9.01 & 12.61 & 68.47 & 23.64 & 16.36 & 10.91 & 49.09 \\
\hline (e) & Commodity price risk & 4.39 & 26.32 & 16.67 & 52.63 & 8.62 & 46.55 & 12.07 & 32.76 \\
\hline (c) & $\begin{array}{l}\text { Term structure risk (change in the long-term vs. } \\
\text { short-term interest rate) }\end{array}$ & 17.12 & 7.21 & 8.11 & 67.57 & 22.81 & 12.28 & 17.54 & 47.37 \\
\hline (g) & Distress risk (probability of banknuptcy) & 8.77 & 14.04 & 13.16 & 64.04 & 12.50 & 23.21 & 14.29 & 50.00 \\
\hline (i) & $\begin{array}{l}\text { "Market-to-book" ratio (ratio of market value of } \\
\text { firm to book value of assets) }\end{array}$ & 4.63 & 8.33 & 12.96 & 74.07 & 20.00 & 12.73 & 12.73 & 54.55 \\
\hline (j) & Momentum (recent stock price performance) & 5.66 & 0.94 & 3.77 & 89.62 & 27.78 & 3.70 & 7.41 & 61.11 \\
\hline
\end{tabular}


Table 5

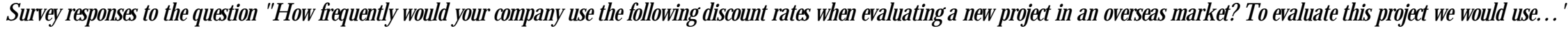

\begin{tabular}{|c|c|c|c|c|c|c|c|c|c|c|c|c|c|c|c|c|c|c|}
\hline & \multicolumn{6}{|c|}{ U.S. } & \multicolumn{6}{|c|}{ U.K. } & \multicolumn{6}{|c|}{ Netherlands } \\
\hline & \multirow{2}{*}{$\begin{array}{c}\% \text { always } \\
\text { or almost } \\
\text { always }\end{array}$} & \multirow{2}{*}{ Mean } & \multicolumn{2}{|c|}{ Size } & \multicolumn{2}{|c|}{ CEO MBA } & \multirow{2}{*}{$\begin{array}{l}\% \text { always } \\
\text { or almost } \\
\text { always }\end{array}$} & \multirow{2}{*}{ Mean } & \multicolumn{2}{|c|}{ Size } & \multicolumn{2}{|c|}{ CEO MBA } & \multirow{2}{*}{$\begin{array}{l}\% \text { always } \\
\text { or almost } \\
\text { always }\end{array}$} & \multirow{2}{*}{ Mean } & \multicolumn{2}{|c|}{ Size } & \multicolumn{2}{|c|}{ CEO MBA } \\
\hline & & & Small & Large & Yes & No & & & Small & Large & Yes & No & & & Small & Large & Yes & No \\
\hline (a) The disoount rate for our entire oompany & 58.79 & 2.50 & 2.50 & 2.50 & 249 & 2.51 & 40.98 & 1.97 & 1.87 & 2.63 & 1.80 & 1.88 & 64.58 & 2.48 & 2.37 & 290 & 2.55 & 2.43 \\
\hline $\begin{array}{l}\text { (d) A risk-matched disoount rate for this particular project } \\
\text { (considering both country and industry) }\end{array}$ & 50.95 & 2.09 & 1.86 & $2.36^{* 1 *}$ & 2.20 & 1.99 & 23.73 & 1.17 & 1.04 & 1.89 & 1.78 & 1.04 & 27.08 & 1.27 & 1.13 & 1.80 & 1.05 & 1.44 \\
\hline $\begin{array}{l}\text { (b) The disoount rate for the overseas market (country } \\
\text { disoount rate) }\end{array}$ & 34.52 & 1.65 & 1.49 & $1.82^{* k}$ & 1.77 & 1.60 & 20.00 & 0.97 & 0.88 & 1.44 & 2.33 & $0.77^{10 k}$ & 14.89 & 1.09 & 0.92 & 1.70 & 1.38 & 0.85 \\
\hline $\begin{array}{l}\text { (c) A divisional disoount rate (if the project line of business } \\
\text { matches a domestic division) }\end{array}$ & 15.61 & 0.95 & 0.82 & $1.09^{12 k}$ & 0.88 & 0.98 & 17.24 & 0.91 & 0.82 & 1.44 & 1.33 & 0.89 & 17.02 & 0.96 & 0.68 & $2.11^{* *}$ & 1.40 & $0.63^{*}$ \\
\hline $\begin{array}{l}\text { (e) A different disoount rate for each oomponent cashflow } \\
\text { that has a different risk characteristic (e.g:: depreciation }\end{array}$ & 9.87 & 0.66 & 0.68 & 0.64 & 0.59 & 0.67 & 10.53 & 0.58 & 0.61 & 0.38 & 1.33 & 0.47 & 2.13 & 0.26 & 0.22 & 0.40 & 0.38 & 0.15 \\
\hline
\end{tabular}
that has a different nisk characteristic (e.g: depreciation vs. operating cash flows)

\begin{tabular}{|c|c|c|c|c|c|c|c|c|c|c|c|c|}
\hline & \multicolumn{6}{|c|}{ Germany } & \multicolumn{6}{|c|}{ Franoe } \\
\hline & \multirow{2}{*}{$\begin{array}{c}\% \text { always } \\
\text { or almos } \\
\text { always }\end{array}$} & \multirow{2}{*}{ Mean } & \multicolumn{2}{|c|}{ Size } & \multicolumn{2}{|c|}{ CEO MBA } & \multirow{2}{*}{$\begin{array}{l}\% \text { always } \\
\text { or almost } \\
\text { always }\end{array}$} & \multirow[b]{2}{*}{ Mean } & \multicolumn{2}{|c|}{ Size } & \multicolumn{2}{|c|}{ CEO MBA } \\
\hline & & & Small & Large & Yes & No & & & Small & Large & Yes & No \\
\hline (a) The discount rate for our entire company & 41.96 & 2.00 & 1.89 & $2.79 *$ & 2.15 & 1.89 & 24.14 & 1.03 & 0.88 & 1.89 & 1.36 & 0.83 \\
\hline $\begin{array}{l}\text { (d) A risk-matched disoount rate for this particular project } \\
\text { (considering both oountry and industry) }\end{array}$ & 25.00 & 1.16 & 1.00 & $2.31^{* *}$ & 1.58 & $0.85^{* *}$ & 27.27 & 1.16 & 1.06 & 1.75 & 1.57 & 0.91 \\
\hline $\begin{array}{l}\text { (b) The disoount rate for the overseas market (oountry } \\
\text { disoount rate) }\end{array}$ & 14.85 & 0.92 & 0.81 & $1.69 *$ & 0.98 & 0.88 & 16.36 & 0.76 & 0.53 & $2.13^{\text {*a }}$ & 0.90 & 0.69 \\
\hline $\begin{array}{l}\text { (c) A divisional disoount rate (if the project line of business } \\
\text { matches a domestic division) }\end{array}$ & 12.00 & 0.69 & 0.67 & 0.85 & 0.77 & 0.63 & 12.50 & 0.70 & 0.60 & 1.25 & 1.24 & $0.37 * *$ \\
\hline $\begin{array}{l}\text { (e) A different disoount rate for each oomponent cashflow } \\
\text { that has a different risk characteristic (e.g: depreciation } \\
\text { vs. operating cash flows) }\end{array}$ & 7.14 & 0.51 & 0.47 & 0.83 & 0.83 & $0.27 * a *$ & 11.32 & 0.62 & 0.54 & 1.14 & 0.79 & 0.53 \\
\hline
\end{tabular}


Table G Multivariate Probit regression output for capital budgeting

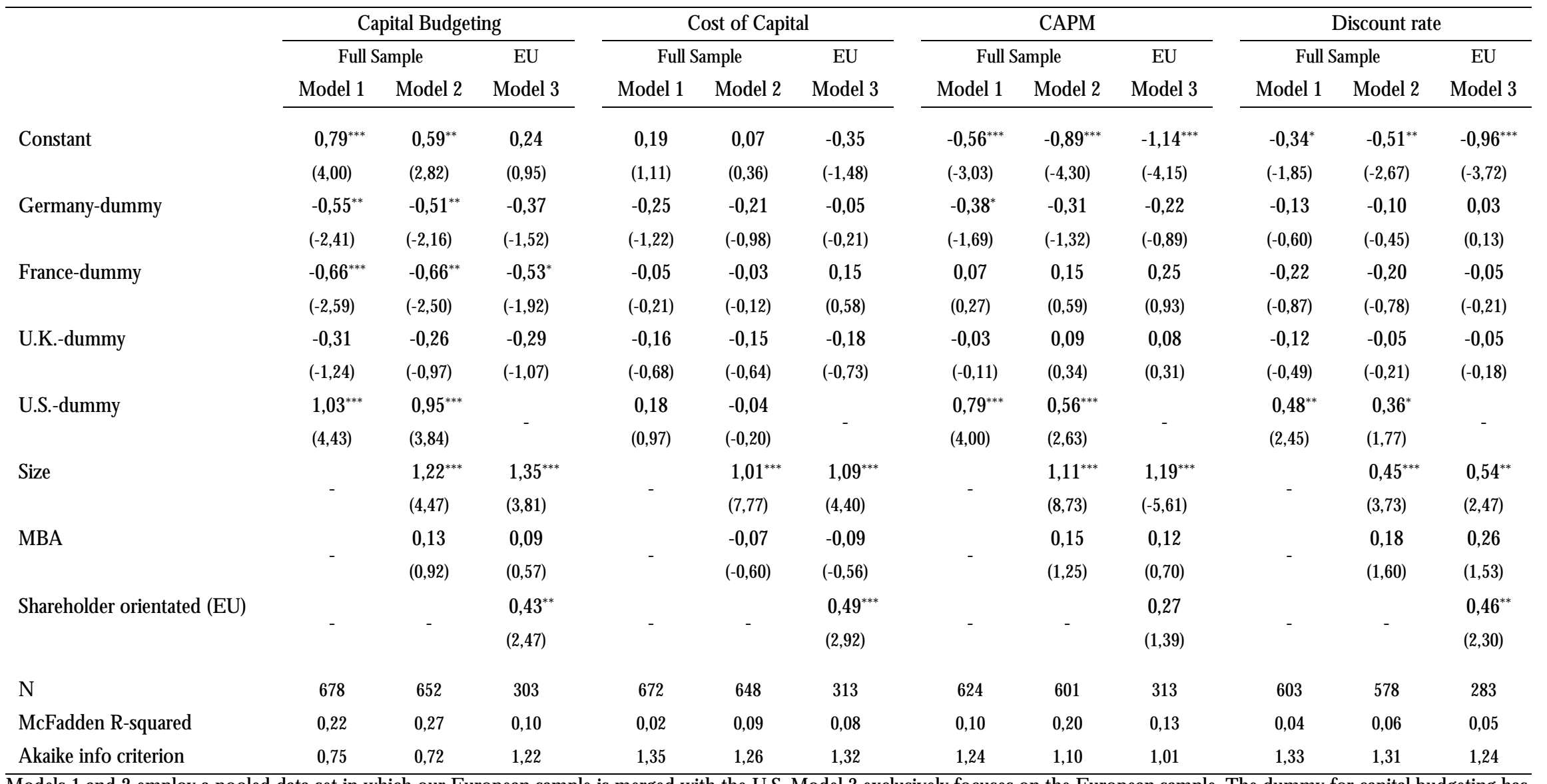

Models 1 and 2 employ a pooled data set in which our Eumoen sample is merged vith the US Model 3 exclusively focuses on the Eumopean sample The dummy for capital budgeting has value one if at least one response to the questions $a$, b, e or $g$ of Table 2 exceeds 2 , or zero otherwise. The dummy for cost of capital equals one if respondents indicate that they calculate the cost of capital, and zero otherwise. The dummy for CAPM has value one if at least one response to the questions b or c of Table 3 exoeeds 2 , and zero otherwise. The dummy for disoount rate equals one if at least one response to the question c, $d$ or e of Table 5 exoeeds 2, or zero otherwise. The dummies of the control vaniables size, MBA, and shareholder onientation are defined as in Table 1. Additional regressions are available on our website. The McFadden R-squared is the likelihood ratio index and is an analogue to the R-squared reported in linear regression models. The Akaike info criterion provides a measure of information that strikes a balanoe between this measure of goodness of fit and parsimonious specification of the model, the lower the value the better the fit of the model. Coefficient estimates marked with*, ${ }^{* * * *}$ are statistically significant at a $10 \%, 5 \%$, and $1 \%$ confidenoe level. 
Table 7

Survey responses to thequestion "What factars affeet howyou hoose theappropiateamount of ddbt for your firm?"

\begin{tabular}{|c|c|c|c|c|c|c|c|c|c|c|c|c|c|c|c|c|c|c|c|}
\hline & & \multicolumn{6}{|c|}{ U.S. } & \multicolumn{6}{|c|}{ U.K. } & \multicolumn{6}{|c|}{ Netherlands } \\
\hline & & \multirow{2}{*}{$\begin{array}{l}\text { \% always } \\
\text { or almost } \\
\text { always }\end{array}$} & \multirow[b]{2}{*}{ Mean } & \multicolumn{2}{|c|}{ Leverage } & \multicolumn{2}{|c|}{$\begin{array}{l}\text { Target debt } \\
\text { ratio }\end{array}$} & \multirow{2}{*}{$\begin{array}{l}\% \text { always } \\
\text { or almost } \\
\text { always }\end{array}$} & \multirow[b]{2}{*}{ Mean } & \multicolumn{2}{|c|}{ Leverage } & \multicolumn{2}{|c|}{$\begin{array}{l}\text { Target debt } \\
\text { ratio }\end{array}$} & \multirow{2}{*}{$\begin{array}{l}\text { \% always } \\
\text { or almost } \\
\text { always }\end{array}$} & \multirow[b]{2}{*}{ Mean } & \multicolumn{2}{|c|}{ Leverage } & \multicolumn{2}{|c|}{$\begin{array}{l}\text { Target debt } \\
\text { ratio }\end{array}$} \\
\hline & & & & Low & High & No & Yes & & & Low & High & No & Yes & & & Low & High & No & Yes \\
\hline (g) & $\begin{array}{l}\text { Financial flexibility (we restrict debt so we have } \\
\text { enough intemal funds available to pursue new } \\
\text { projects when they come along) }\end{array}$ & 59.38 & 2.59 & 2.61 & 2.60 & 2.63 & 2.54 & 50.00 & 2.13 & 1.88 & $2.83^{* *}$ & 1.32 & $2.63^{* 1 *}$ & 51.06 & 2.32 & 2.41 & 2.17 & 2.29 & 2.33 \\
\hline (d) & Our credit rating (as assigned by rating agencies) & 57.10 & 2.46 & 2.29 & $2.64^{* *}$ & 2.19 & $2.73^{\text {rata }}$ & 27.42 & 1.48 & 1.36 & 1.63 & 1.00 & $1.77^{* 3 *}$ & 34.04 & 1.53 & 1.14 & $2.17 *$ & 1.29 & 1.64 \\
\hline (h) & The volatility of our eamings and cash flows & 48.08 & 2.32 & 2.25 & 2.32 & 2.34 & 2.26 & 35.48 & 1.73 & 1.29 & $2.26^{1 *}$ & 1.12 & $2.17^{\text {tatk }}$ & 42.55 & 2.06 & 2.14 & 1.94 & 1.79 & 2.18 \\
\hline (a) & The tax advantage of interest deductibility & 44.85 & 2.07 & 1.99 & $2.26^{* *}$ & 2.03 & 2.13 & 30.16 & 1.68 & 1.41 & $2.21^{*}$ & 0.76 & $2.33^{* 2 *}$ & 37.50 & 1.90 & 1.93 & 1.84 & 1.36 & 2.12 \\
\hline (e) & The transactions costs and fees for issuing debt & 33.52 & 1.95 & 1.94 & 1.87 & 2.02 & 1.89 & 25.40 & 1.68 & 1.29 & $2.11^{* *}$ & 1.04 & $2.06+2 x$ & 15.22 & 1.26 & 1.25 & 1.28 & 0.92 & 1.39 \\
\hline (c) & The debt levels of other fimms in our industry & 23.40 & 1.49 & 1.36 & $1.70^{+120 k}$ & 1.37 & $1.60^{2 *}$ & 16.13 & 1.11 & 1.12 & 1.00 & 0.84 & $1.34^{*}$ & 26.53 & 1.37 & 0.87 & $2.16^{10 x}$ & 0.60 & $1.71^{\text {*ax }}$ \\
\hline (b) & $\begin{array}{l}\text { The potential costs of banknuptcy, near-banknuptcy, } \\
\text { or financial distress }\end{array}$ & 21.35 & 1.24 & 1.16 & $1.37^{\# *}$ & 1.32 & 1.19 & 30.16 & 1.37 & 0.88 & $2.16^{\text {tak }}$ & 0.80 & $1.81^{* 1 *}$ & 27.08 & 1.42 & 1.38 & 1.47 & 1.00 & 1.59 \\
\hline (i) & $\begin{array}{l}\text { We limit debt so our customers/ suppliers are not } \\
\text { womied about our fim going out of business }\end{array}$ & 18.72 & 1.24 & 1.34 & 1.20 & 1.27 & 1.24 & 34.43 & 1.62 & 1.27 & $2.06^{1 *}$ & 1.08 & $2.03^{* 1+k}$ & 8.33 & 0.96 & 0.93 & 1.00 & 0.80 & 1.03 \\
\hline (n) & $\begin{array}{l}\text { We restrict our bonrowing so that profits from } \\
\text { new/ future projects can be captured fully by } \\
\text { shareholders and do not have to be paid out as } \\
\text { interest to debtholders }\end{array}$ & 12.57 & 1.01 & 1.18 & $0.83^{\text {rat }}$ & 1.03 & 0.99 & 21.05 & 1.30 & 1.27 & 1.29 & 1.08 & 1.44 & 8.89 & 0.73 & 0.86 & 0.50 & 0.92 & 0.66 \\
\hline (j) & $\begin{array}{l}\text { We try to have enough debt that we are not an } \\
\text { attractive takeover target }\end{array}$ & 4.75 & 0.73 & 0.62 & $0.90^{1+2 k}$ & 0.71 & 0.77 & 0.00 & 0.58 & 0.53 & 0.71 & 0.32 & $0.79 *$ & 2.13 & 0.38 & 0.24 & 0.61 & 0.21 & 0.45 \\
\hline (f) & $\begin{array}{l}\text { The personal tax cost our investors faoe when they } \\
\text { reoeive interest inoome }\end{array}$ & 4.79 & 0.68 & 0.68 & 0.63 & 0.73 & $0.58^{*}$ & 3.23 & 0.65 & 0.50 & 0.68 & 0.52 & 0.69 & 4.35 & 0.61 & 0.68 & 0.50 & 0.29 & $0.75^{*}$ \\
\hline (k) & $\begin{array}{l}\text { If we issue debt our competitors know that we are } \\
\text { very unlikely to reduce our output/ sales }\end{array}$ & 2.25 & 0.40 & 0.33 & $0.47 * *$ & 0.44 & 0.36 & 3.33 & 0.60 & 0.55 & 0.74 & 0.60 & 0.64 & 0.00 & 0.24 & 0.21 & 0.29 & 0.15 & 0.27 \\
\hline (m) & $\begin{array}{l}\text { To ensure that upper management works hard and } \\
\text { efficiently, we issue sufficient debt to make sure that } \\
\text { a large portion of our cash flow is committed to } \\
\text { interest payments }\end{array}$ & 1.69 & 0.33 & 0.22 & $0.49^{1+2 k}$ & 0.34 & 0.34 & 4.84 & 0.52 & 0.47 & 0.47 & 0.52 & 0.49 & 2.22 & 0.27 & 0.21 & 0.35 & 0.00 & $0.36^{* 2 *}$ \\
\hline (l) & $\begin{array}{l}\text { A high debt ratio helps us bargain for conoessions } \\
\text { from our employees }\end{array}$ & 0.00 & 0.16 & 0.13 & $0.19^{*}$ & 0.16 & 0.18 & 0.00 & 0.27 & 0.29 & 0.21 & 0.32 & 0.23 & 0.00 & 0.24 & 0.24 & 0.24 & 0.23 & 0.24 \\
\hline
\end{tabular}


Table 7- continued

Survey responses to thequestion "What factars affeet howyou hoose theappropiateamount of ddbt for your firm?"

\begin{tabular}{|c|c|c|c|c|c|c|c|c|c|c|c|c|c|}
\hline & & \multicolumn{6}{|c|}{ Germany } & \multicolumn{6}{|c|}{ France } \\
\hline & & \multirow{2}{*}{$\begin{array}{l}\% \text { always } \\
\text { or almost } \\
\text { always }\end{array}$} & \multirow[b]{2}{*}{ Mean } & \multicolumn{2}{|c|}{ Leverage } & \multicolumn{2}{|c|}{$\begin{array}{l}\text { Target debt } \\
\text { ratio } \\
\end{array}$} & \multirow{2}{*}{$\begin{array}{c}\text { \% always } \\
\text { or almost } \\
\text { always }\end{array}$} & \multirow[b]{2}{*}{ Mean } & \multicolumn{2}{|c|}{ Leverage } & \multicolumn{2}{|c|}{$\begin{array}{l}\text { Target debt } \\
\text { ratio }\end{array}$} \\
\hline & & & & Low & High & No & Yes & & & Low & High & No & Yes \\
\hline (g) & $\begin{array}{l}\text { Financial flexibility (we restrict debt so we have } \\
\text { enough intemal funds available to pursue new } \\
\text { projects when they come along) }\end{array}$ & 47.83 & 2.17 & 2.21 & 2.09 & 2.17 & 2.16 & 37.25 & 1.84 & 1.81 & 2.00 & 1.61 & $2.40^{1 * k}$ \\
\hline (d) & Our credit rating (as assigned by rating agencies) & 38.60 & 1.85 & 1.71 & 2.07 & 1.08 & $2.21^{*}$ ** & 30.19 & 1.58 & 1.60 & 1.50 & 1.37 & 2.13 \\
\hline (h) & The volatility of our eamings and cash flows & 30.97 & 1.67 & 1.75 & 1.56 & 1.36 & $1.82^{*}$ & 34.78 & 1.54 & 1.50 & 1.83 & 1.15 & $2.54^{* 10 *}$ \\
\hline (a) & The tax advantage of interest deductibility & 21.05 & 1.28 & 1.23 & 1.36 & 1.00 & 1.41 & 29.63 & 1.57 & 1.57 & 1.60 & 1.50 & 1.75 \\
\hline (e) & The transactions costs and fees for issuing debt & 26.32 & 1.50 & 1.39 & 1.67 & 1.42 & 1.54 & 21.15 & 1.42 & 1.33 & 1.80 & 1.19 & $2.00^{*}$ \\
\hline (c) & The debt levels of other firms in our industry & 14.04 & 1.14 & 1.07 & 1.24 & 0.83 & $1.28^{2 \%}$ & 12.96 & 1.24 & 1.25 & 1.20 & 1.21 & 1.31 \\
\hline (b) & $\begin{array}{l}\text { The potential oosts of banknuptcy, near-banknuptcy, } \\
\text { or financial distress }\end{array}$ & 7.08 & 0.65 & 0.56 & 0.78 & 0.58 & 0.68 & 24.07 & 1.22 & 1.09 & 1.89 & 1.21 & 1.27 \\
\hline (i) & $\begin{array}{l}\text { We limit debt so our customers/ suppliers are not } \\
\text { womied about our firm going out of business }\end{array}$ & 15.04 & 1.10 & 1.06 & 1.16 & 1.08 & 1.10 & 31.91 & 1.62 & 1.53 & 2.14 & 1.58 & 1.71 \\
\hline (n) & $\begin{array}{l}\text { We restrict our borrowing so that profits from } \\
\text { new/ future projects can be captured fully by } \\
\text { shareholders and do not have to be paid out as } \\
\text { interest to debtholders }\end{array}$ & 19.27 & 1.06 & 1.24 & $0.77 *$ & 1.24 & 0.97 & 22.73 & 1.27 & 1.13 & $2.17 *$ & 1.19 & 1.50 \\
\hline (j) & $\begin{array}{l}\text { We try to have enough debt that we are not an } \\
\text { attractive takeover target }\end{array}$ & 2.68 & 0.48 & 0.27 & $0.80^{\text {takk }}$ & 0.26 & $0.58^{1 *}$ & 6.52 & 0.61 & 0.53 & 1.17 & 0.58 & 0.69 \\
\hline (f) & $\begin{array}{l}\text { The personal tax cost our investors faoe when they } \\
\text { reoeive interest inoome }\end{array}$ & 6.31 & 0.75 & 0.75 & 0.75 & 0.86 & 0.69 & 10.00 & 0.84 & 0.80 & 1.00 & 0.69 & 1.21 \\
\hline (k) & $\begin{array}{l}\text { If we issue debt our competitors know that we are } \\
\text { very unlikely to reduce our output/ sales }\end{array}$ & 2.68 & 0.43 & 0.33 & 0.58 & 0.42 & 0.43 & 2.22 & 0.40 & 0.31 & $1.00^{2 *}$ & 0.36 & 0.50 \\
\hline (m) & $\begin{array}{l}\text { To ensure that upper management works hard and } \\
\text { efficiently, we issue sufficient debt to make sure that } \\
\text { a large portion of our cash flow is oommitted to } \\
\text { interest payments }\end{array}$ & 0.93 & 0.31 & 0.28 & 0.36 & 0.25 & 0.35 & 7.32 & 0.63 & 0.66 & 0.50 & 0.60 & 0.73 \\
\hline (l) & $\begin{array}{l}\text { A high debt ratio helps us bargain for conoessions } \\
\text { from our employees }\end{array}$ & 0.92 & 0.30 & 0.28 & 0.34 & 0.28 & 0.32 & 0.00 & 0.41 & 0.32 & 1.00 & 0.47 & 0.25 \\
\hline
\end{tabular}


Table 8

Survey responses to thequestion "What other factars affeet your fimns ddet pdiog?"

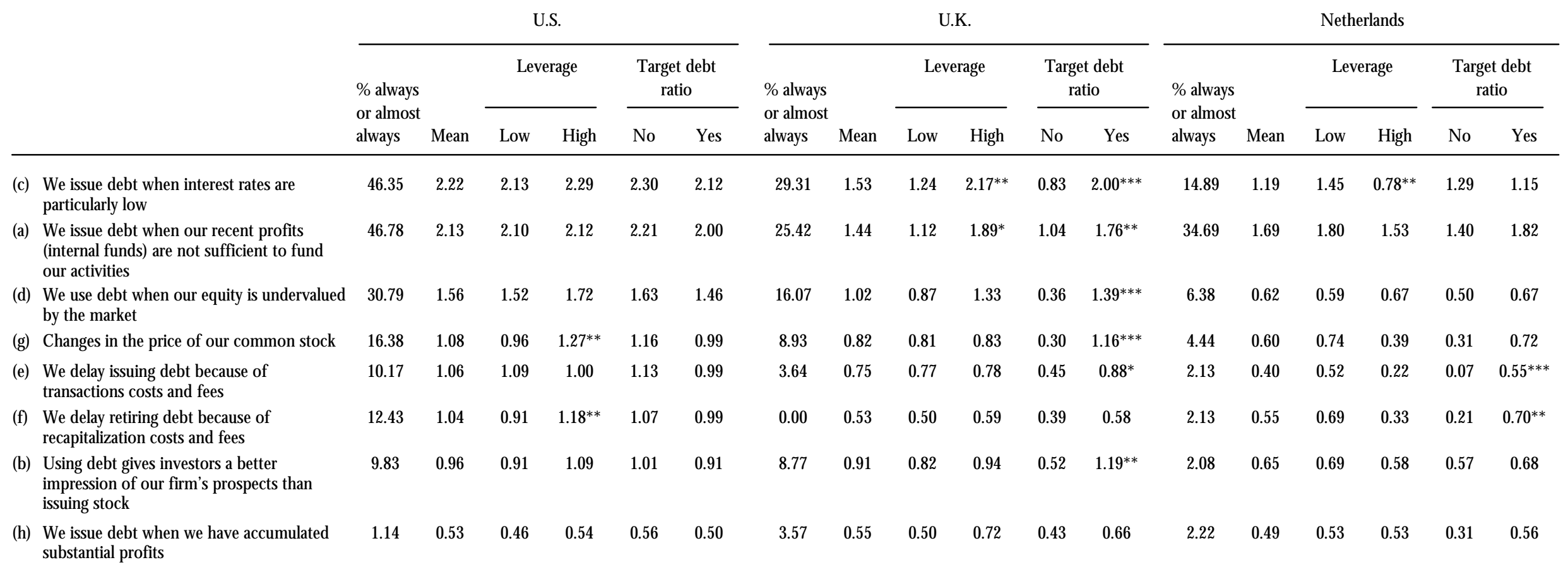


Table 8- continued

Survey responses to thequestion "What other factars affeet your fimms ddtt pdigy?"

\begin{tabular}{|c|c|c|c|c|c|c|c|c|c|c|c|c|c|}
\hline & & \multicolumn{6}{|c|}{ Germany } & \multicolumn{6}{|c|}{ France } \\
\hline & & \multirow{2}{*}{$\begin{array}{l}\text { \% always } \\
\text { or almost } \\
\text { always }\end{array}$} & \multirow[b]{2}{*}{ Mean } & \multicolumn{2}{|c|}{ Leverage } & \multicolumn{2}{|c|}{$\begin{array}{l}\text { Target debt } \\
\text { ratio }\end{array}$} & \multirow{2}{*}{$\begin{array}{l}\text { \% always } \\
\text { or almost } \\
\text { always }\end{array}$} & \multirow[b]{2}{*}{ Mean } & \multicolumn{2}{|c|}{ Leverage } & \multicolumn{2}{|c|}{$\begin{array}{l}\text { Target debt } \\
\text { ratio }\end{array}$} \\
\hline & & & & Low & High & No & Yes & & & Low & High & No & Yes \\
\hline (c) & $\begin{array}{l}\text { We issue debt when interest rates are } \\
\text { particularly low }\end{array}$ & 32.76 & 1.87 & 1.80 & 1.98 & 1.68 & 1.96 & 24.49 & 1.33 & 1.25 & 1.67 & 1.29 & 1.43 \\
\hline (a) & $\begin{array}{l}\text { We issue debt when our recent profits } \\
\text { (intemal funds) are not sufficient to fund } \\
\text { our activities }\end{array}$ & 54.31 & 2.30 & 2.11 & $260^{*}$ & 1.64 & $2.60^{110 k}$ & 23.53 & 1.24 & 1.13 & 1.64 & 0.97 & $1.81^{* *}$ \\
\hline (d) & $\begin{array}{l}\text { We use debt when our equity is undervalued } \\
\text { by the market }\end{array}$ & 6.31 & 0.45 & 0.56 & 0.28 & 0.37 & 0.49 & 8.16 & 0.80 & 0.73 & 1.11 & 0.69 & 1.07 \\
\hline (g) & Changes in the price of our common stock & 2.80 & 0.46 & 0.60 & $0.24^{* *}$ & 0.49 & 0.44 & 4.65 & 0.65 & 0.54 & $1.33^{*}$ & 0.61 & 0.75 \\
\hline (e) & $\begin{array}{l}\text { We delay issuing debt because of } \\
\text { transactions costs and fees }\end{array}$ & 5.26 & 0.75 & 0.75 & 0.73 & 0.64 & 0.79 & 8.33 & 0.71 & 0.59 & 1.22 & 0.76 & 0.57 \\
\hline (f) & $\begin{array}{l}\text { We delay retining debt because of } \\
\text { recapitalization oosts and fees }\end{array}$ & 7.02 & 0.89 & 0.90 & 0.87 & 1.00 & 0.83 & 4.35 & 0.59 & 0.46 & $1.11 *$ & 0.59 & 0.57 \\
\hline (b) & $\begin{array}{l}\text { Using debt gives investors a better } \\
\text { impression of our firm's prospects than } \\
\text { issuing stock }\end{array}$ & 4.31 & 0.75 & 0.61 & $0.98^{\text {rkt }}$ & 0.68 & 0.78 & 11.76 & 1.06 & 0.90 & $1.78^{*}$ & 0.89 & 1.47 \\
\hline (h) & $\begin{array}{l}\text { We issue debt when we have aocumulated } \\
\text { substantial profits }\end{array}$ & 5.45 & 0.62 & 0.61 & 0.63 & 0.53 & 0.66 & 4.65 & 0.58 & 0.51 & 1.00 & 0.61 & 0.50 \\
\hline
\end{tabular}


Table 9

Survey responees to thequestion "What factars affeet your firms dhice between shat-and longtem ddb?"

\begin{tabular}{|c|c|c|c|c|c|c|c|c|c|c|c|c|c|c|c|c|c|c|c|}
\hline & & \multicolumn{6}{|c|}{ U.S. } & \multicolumn{6}{|c|}{ U.K. } & \multicolumn{6}{|c|}{ Netherlands } \\
\hline & & \multirow{2}{*}{$\begin{array}{l}\text { \% always } \\
\text { or almost } \\
\text { always }\end{array}$} & \multirow[b]{2}{*}{ Mean } & \multicolumn{2}{|c|}{ Leverage } & \multicolumn{2}{|c|}{$\begin{array}{l}\text { Target debt } \\
\text { ratio }\end{array}$} & \multirow{2}{*}{$\begin{array}{l}\text { \% always } \\
\text { or almost } \\
\text { always }\end{array}$} & \multirow[b]{2}{*}{ Mean } & \multicolumn{2}{|c|}{ Leverage } & \multicolumn{2}{|c|}{$\begin{array}{l}\text { Target debt } \\
\text { ratio }\end{array}$} & \multirow{2}{*}{$\begin{array}{l}\text { \% always } \\
\text { or almost } \\
\text { always }\end{array}$} & \multirow[b]{2}{*}{ Mean } & \multicolumn{2}{|c|}{ Leverage } & \multicolumn{2}{|c|}{$\begin{array}{l}\text { Target debt } \\
\text { ratio }\end{array}$} \\
\hline & & & & Low & High & No & Yes & & & Low & High & No & Yes & & & Low & High & No & Yes \\
\hline (b) & $\begin{array}{l}\text { Matching the maturity of our debt with the } \\
\text { life of our assets }\end{array}$ & 63.25 & 2.60 & 2.57 & 2.63 & 2.53 & 2.66 & 58.73 & 2.16 & 1.88 & $2.83^{* *}$ & 1.50 & $2.54^{* *}$ & 57.45 & 2.55 & 2.61 & 2.47 & 2.06 & $2.81^{*}$ \\
\hline (g) & $\begin{array}{l}\text { We issue long-term debt to minimize the } \\
\text { nisk of having to refinanoe in "bad times" }\end{array}$ & 48.83 & 2.15 & 1.95 & $2.55^{121 *}$ & 2.00 & $2.36^{100 k}$ & 28.81 & 1.39 & 0.91 & 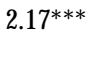 & 0.46 & $2.03^{19 k}$ & 47.62 & $1.90^{* *}$ & 1.87 & 1.95 & 1.57 & 2.07 \\
\hline (a) & $\begin{array}{l}\text { We issue short tem when short term } \\
\text { interest rates are low compared to long term } \\
\text { rates }\end{array}$ & 35.94 & 1.89 & 1.82 & 1.93 & 1.93 & 1.85 & 16.39 & 1.11 & 0.94 & 1.44 & 0.50 & $1.50^{\text {rate }}$ & 25.00 & 1.48 & 1.56 & 1.37 & 1.53 & 1.45 \\
\hline (c) & $\begin{array}{l}\text { We issue short-term when we are waiting } \\
\text { for long-term market interest rates to } \\
\text { decline }\end{array}$ & 28.70 & 1.78 & 1.67 & $1.90^{1 * k}$ & 1.72 & 1.87 & 11.48 & 0.89 & 0.55 & $1.44^{* 12 *}$ & 0.38 & $1.22^{* 2 *}$ & 13.95 & 1.05 & 1.17 & 0.89 & 0.71 & 1.21 \\
\hline (d) & $\begin{array}{l}\text { We bonrow short-term so that retums from } \\
\text { new projects can be captured more fully by } \\
\text { shareholders, rather than committing to pay } \\
\text { long-term profits as interest to debtholders }\end{array}$ & 9.48 & 0.94 & 1.01 & $0.85^{*}$ & 0.96 & 0.90 & 12.90 & 0.82 & 0.73 & 0.89 & 0.67 & 0.86 & 9.09 & $0.80^{1 * k}$ & 0.88 & 0.68 & 0.71 & 0.83 \\
\hline (e) & $\begin{array}{l}\text { We expect our credit rating to improve, so } \\
\text { we bonrow short-term until it does }\end{array}$ & 8.99 & 0.85 & 0.79 & 0.99* & 0.98 & $0.65+10 k$ & 5.00 & 0.57 & 0.42 & 0.83 & 0.25 & $0.77 \% k$ & 4.65 & 0.47 & 0.42 & 0.53 & 0.50 & 0.45 \\
\hline (f) & $\begin{array}{l}\text { Bonrowing short-term reduoes the chance } \\
\text { that our fimm will want to take on risky } \\
\text { projects }\end{array}$ & 4.02 & 0.53 & 0.56 & 0.49 & 0.55 & 0.51 & 1.72 & 0.45 & 0.31 & 0.59 & 0.33 & 0.55 & 2.33 & 0.40 & 0.29 & 0.53 & 0.36 & 0.41 \\
\hline
\end{tabular}


Table 9- continued

Survey responses to thequestion "What factars affeet your firms dhice between shat-and longtemddt?"

\begin{tabular}{|c|c|c|c|c|c|c|c|c|c|c|c|c|c|}
\hline & & \multicolumn{6}{|c|}{ Gemmany } & \multicolumn{6}{|c|}{ Franoe } \\
\hline & & \multirow{2}{*}{$\begin{array}{l}\% \text { always } \\
\text { or almost } \\
\text { always }\end{array}$} & \multirow[b]{2}{*}{ Mean } & \multicolumn{2}{|c|}{ Leverage } & \multicolumn{2}{|c|}{$\begin{array}{l}\text { Target debt } \\
\text { ratio } \\
\end{array}$} & \multirow{2}{*}{$\begin{array}{l}\% \text { always } \\
\text { or almost } \\
\text { always }\end{array}$} & \multirow[b]{2}{*}{ Mean } & \multicolumn{2}{|c|}{ Leverage } & \multicolumn{2}{|c|}{$\begin{array}{l}\text { Target debt } \\
\text { ratio }\end{array}$} \\
\hline & & & & Low & High & No & Yes & & & Low & High & No & Yes \\
\hline (b) & $\begin{array}{l}\text { Matching the maturity of our debt with the } \\
\text { life of our assets }\end{array}$ & 60.34 & 2.55 & 2.28 & $2.98^{121 k}$ & 1.89 & $2.86^{12 k}$ & 31.91 & 1.68 & 1.70 & 1.78 & 1.42 & $2.38^{* 2 *}$ \\
\hline (g) & $\begin{array}{l}\text { We issue long-term debt to minimize the } \\
\text { risk of having to refinanoe in "bad times" }\end{array}$ & 51.75 & 2.24 & 1.93 & $2.71^{* 1+k}$ & 2.03 & 2.33 & 31.91 & 1.68 & 1.59 & 2.13 & 1.31 & $2.47 * *$ \\
\hline (a) & $\begin{array}{l}\text { We issue short tem when short tem } \\
\text { interest rates are low oompared to long term } \\
\text { rates }\end{array}$ & 37.39 & 1.93 & 1.90 & 1.98 & 1.79 & 2.00 & 30.19 & 1.58 & 1.47 & 2.10 & 1.61 & 1.53 \\
\hline (c) & $\begin{array}{l}\text { We issue short-term when we are waiting } \\
\text { for long-term market interest rates to } \\
\text { decline }\end{array}$ & 37.39 & 1.90 & 1.80 & 2.04 & 1.54 & $2.06^{*}$ & 16.98 & 1.15 & 1.07 & 1.56 & 1.06 & 1.35 \\
\hline (d) & $\begin{array}{l}\text { We borrow short-term so that retums from } \\
\text { new projects can be captured more fully by } \\
\text { shareholders, rather than committing to pay } \\
\text { long-tem profits as interest to debtholders }\end{array}$ & 4.42 & 0.54 & 0.56 & 0.51 & 0.73 & 0.45 & 13.21 & 0.83 & 0.70 & 1.40 & 0.64 & 1.24 \\
\hline (e) & $\begin{array}{l}\text { We expect our credit rating to improve, so } \\
\text { we bonow short-term until it does }\end{array}$ & 7.89 & 0.58 & 0.45 & 0.78 & 0.57 & 0.58 & 11.76 & 0.75 & 0.55 & 1.67 & 0.66 & 0.94 \\
\hline (f) & $\begin{array}{l}\text { Borrowing short-term reduces the chance } \\
\text { that our firm will want to take on risky } \\
\text { projects }\end{array}$ & 6.31 & 0.59 & 0.42 & $0.86^{* *}$ & 0.42 & 0.68 & 15.22 & 0.83 & 0.75 & 1.33 & 0.72 & 1.07 \\
\hline
\end{tabular}


Table 1a Multivariate Probit regression output for capital structure

\begin{tabular}{|c|c|c|c|c|c|c|c|c|c|c|c|c|}
\hline & \multicolumn{3}{|c|}{ Flexibility } & \multicolumn{3}{|c|}{ Target } & \multicolumn{3}{|c|}{ Tax advantage } & \multicolumn{3}{|c|}{ Banknuptcy oosts } \\
\hline & \multicolumn{2}{|c|}{ Full Sample } & \multirow{2}{*}{$\begin{array}{c}\text { EU } \\
\text { Model } 3\end{array}$} & \multicolumn{2}{|c|}{ Full Sample } & \multirow{2}{*}{$\begin{array}{c}\text { EU } \\
\text { Model } 3\end{array}$} & \multicolumn{2}{|c|}{ Full Sample } & \multirow{2}{*}{$\begin{array}{c}\text { EU } \\
\text { Model } 3\end{array}$} & \multicolumn{2}{|c|}{ Full Sample } & \multirow{2}{*}{$\begin{array}{c}\text { EU } \\
\text { Model } 3\end{array}$} \\
\hline & Model 1 & Model 2 & & Model 1 & Model 2 & & Model 1 & Model 2 & & Model 1 & Model 2 & \\
\hline Constant & $\begin{array}{c}0.03 \\
(0,15)\end{array}$ & $\begin{array}{l}-0,47^{* *} \\
(-2,12)\end{array}$ & $\begin{array}{l}-0.65^{* *} \\
(-2,21)\end{array}$ & $\begin{array}{l}0.67^{\text {*** }} \\
(3,57)\end{array}$ & $\begin{array}{r}0,10 \\
(0,46)\end{array}$ & $\begin{array}{c}0.21 \\
(0,81)\end{array}$ & $\begin{array}{l}-0.32^{*} \\
(-1.73)\end{array}$ & $\begin{array}{l}-0,95^{* * *} \\
(-4,12)\end{array}$ & $\begin{array}{l}-1,25^{\text {tak }} \\
(-3,82)\end{array}$ & $\begin{array}{c}0,13 \\
(0,73)\end{array}$ & $\begin{array}{l}-0,18 \\
(-0,85)\end{array}$ & $\begin{array}{l}-0,46 \\
(-1,55)\end{array}$ \\
\hline Germany-dummy & $\begin{array}{l}-0.07 \\
(-0,33)\end{array}$ & $\begin{array}{c}0,07 \\
(0,31)\end{array}$ & $\begin{array}{c}0,12 \\
(0,50)\end{array}$ & $\begin{array}{l}-0.11 \\
(-0,52)\end{array}$ & $\begin{array}{r}0,02 \\
(0,07)\end{array}$ & $\begin{array}{l}-0.04 \\
(-0,18)\end{array}$ & $\begin{array}{l}-0.49^{* *} \\
(-2,14)\end{array}$ & $\begin{array}{l}-0,39^{*} \\
(-1,65)\end{array}$ & $\begin{array}{l}-0,33 \\
(-1,32)\end{array}$ & $\begin{array}{l}-0,46^{\text {to* }} \\
(-2,10)\end{array}$ & $\begin{array}{l}-0,46^{+*} \\
(-2,10)\end{array}$ & $\begin{array}{l}-0,41^{*} \\
(-1,74)\end{array}$ \\
\hline Franoe-dummy & $\begin{array}{l}-0.37 \\
(-1,45)\end{array}$ & $\begin{array}{l}-0,32 \\
(-1,23)\end{array}$ & $\begin{array}{l}-0.30 \\
(-1,06)\end{array}$ & $\begin{array}{l}-0,86^{\text {tok }} \\
(-3,46)\end{array}$ & $\begin{array}{l}-0,78^{\text {w** }} \\
(-3,02)\end{array}$ & $\begin{array}{l}-0.84^{+\infty * *} \\
(-3.15)\end{array}$ & $\begin{array}{l}-0.23 \\
(-0,90)\end{array}$ & $\begin{array}{l}-0,05 \\
(-0,19)\end{array}$ & $\begin{array}{c}0,12 \\
(0,43)\end{array}$ & $\begin{array}{l}-0,08 \\
(-0,31)\end{array}$ & $\begin{array}{r}0,07 \\
(0,27)\end{array}$ & $\begin{array}{r}0,18 \\
(0,62)\end{array}$ \\
\hline U.K.-dummy & $\begin{array}{l}-0,03 \\
(-0,11)\end{array}$ & $\begin{array}{r}0,09 \\
(0,35)\end{array}$ & $\begin{array}{c}0,13 \\
(0,54)\end{array}$ & $\begin{array}{c}-0,41^{*} \\
(-1,70)\end{array}$ & $\begin{array}{l}-0,31 \\
(-1,23)\end{array}$ & $\begin{array}{l}-0,30 \\
(-1,14)\end{array}$ & $\begin{array}{l}-0,20 \\
(-0,81)\end{array}$ & $\begin{array}{l}-0,09 \\
(-0,35)\end{array}$ & $\begin{array}{l}-0,11 \\
(-0,41)\end{array}$ & $\begin{array}{l}-0,17 \\
(-0,72)\end{array}$ & $\begin{array}{l}-0,12 \\
(-0,48)\end{array}$ & $\begin{array}{l}-0,09 \\
(-0,37)\end{array}$ \\
\hline U.S.-dummy & $\begin{array}{c}0,21 \\
(1,08)\end{array}$ & $\begin{array}{c}0,32 \\
(1,56)\end{array}$ & - & $\begin{array}{c}0.21 \\
(1,03)\end{array}$ & $\begin{array}{r}0,29 \\
(1,31)\end{array}$ & - & $\begin{array}{r}0.19 \\
(0,97)\end{array}$ & $\begin{array}{r}0,05 \\
(0,26)\end{array}$ & - & $\begin{array}{l}-0,01 \\
(-0,05)\end{array}$ & $\begin{array}{l}-0,02 \\
(-0,11)\end{array}$ & - \\
\hline Leverage & - & $\begin{array}{l}-0,15 \\
(-1,31)\end{array}$ & $\begin{array}{l}-0.15 \\
(-0,89)\end{array}$ & - & $\begin{array}{l}0,61^{*+* *} \\
(4,66)\end{array}$ & $\begin{array}{l}0.72^{\text {we* }} \\
(3,93)\end{array}$ & - & $\begin{array}{c}0,07 \\
(0,60)\end{array}$ & $\begin{array}{l}-0,05 \\
(0,28)\end{array}$ & - & $\begin{array}{c}0,05 \\
(0,40)\end{array}$ & $\begin{array}{l}-0,05 \\
(-0,30)\end{array}$ \\
\hline Target leverage & - & $\begin{array}{c}0,24^{*} \\
(1,76)\end{array}$ & $\begin{array}{l}0.33^{* *} \\
(1,88)\end{array}$ & - & - & - & - & $\begin{array}{l}0,41^{* *} \\
(2,78)\end{array}$ & $\begin{array}{l}0,65^{+12 *} \\
(3,18)\end{array}$ & - & $\begin{array}{l}0,42^{\text {wak }} \\
(3,11)\end{array}$ & $\begin{array}{l}0,63^{+* * *} \\
(3,46)\end{array}$ \\
\hline Size & - & $\begin{array}{c}0,10 \\
(0,74)\end{array}$ & $\begin{array}{r}0.24 \\
(1,02)\end{array}$ & - & $\begin{array}{l}0,41^{*+1 *} \\
(2,63)\end{array}$ & $\begin{array}{l}0.87^{10 *} \\
(3,25)\end{array}$ & - & $\begin{array}{l}0,72^{\text {wk* }} \\
(5,37)\end{array}$ & $\begin{array}{l}0,69^{t a *} \\
(2,98)\end{array}$ & - & $\begin{array}{l}-0,12 \\
(-0,92)\end{array}$ & $\begin{array}{l}-0,11 \\
(-0,45)\end{array}$ \\
\hline Dividend & - & $\begin{array}{l}0,48^{2 * * *} \\
(4,04)\end{array}$ & $\begin{array}{l}0.60^{12 *} \\
(3,51)\end{array}$ & - & $\begin{array}{l}0,46^{\text {sak }} \\
(3,74)\end{array}$ & $\begin{array}{l}0.41^{* *} \\
(2,53)\end{array}$ & - & $\begin{array}{r}0,18 \\
(1,43)\end{array}$ & $\begin{array}{l}-0,02 \\
(-0,11)\end{array}$ & - & $\begin{array}{r}0,02 \\
(0,15)\end{array}$ & $\begin{array}{l}-0,02 \\
(-0,10)\end{array}$ \\
\hline Shareholder onientated (EU) & - & - & $\begin{array}{l}-0.01 \\
(-0,05)\end{array}$ & - & - & $\begin{array}{l}-0.19 \\
(-1,09)\end{array}$ & - & - & $\begin{array}{r}0,33 \\
(1,57)\end{array}$ & - & - & $\begin{array}{r}0,15 \\
(0,79)\end{array}$ \\
\hline $\mathbf{N}$ & 632 & 563 & 303 & 674 & 616 & 313 & 639 & 570 & 280 & 632 & 562 & 268 \\
\hline McFadden R-squared & 0.02 & 0,05 & 0.09 & 0.06 & 0,15 & 0.14 & 0.03 & 0,11 & 0.11 & 0,01 & 0,03 & 0,06 \\
\hline Akaike info criterion & 1.38 & 1,34 & 1.23 & 1.11 & 1,01 & 1.18 & 1.30 & 1,21 & 1.11 & 1,38 & 1,38 & 1,37 \\
\hline
\end{tabular}

Models 1 and 2 employ a pooled data set in which our European sample is merged with the U.S. Model 3 exclusively focuses on the European sample. The dummy for flexibility has value one if at least one response to the question g of Table 7 exceeds 2, or zero otherwise. The dummy for target equals one if the respondents indicate that they set a target debt ratio, and zero otherwise. The dummy for tax advantage has value one if the response to the questions a of Table 7 exoeeds 2, and zero otherwise. The dummy for banknuptcy oosts equals one if at least one response to the question $\mathrm{b}$ and $\mathrm{h}$ of Table 7 exceeds 2, or zero othervise. The dummies of the control variables size, MBA, and shareholder orientation are defined as in Table 1. Additional regressions are available on our website. The McFadden R-squared is the likelihood ratio index and is an analogue to the R-squared reported in linear regression models. The Akaike info criterion provides a measure of information that strikes a balanœe between this measure of goodness of fit and parsimonious specification of the model, the lower the value the better the fit of the model. Coefficient estimates marked with ***, ${ }^{* * *}$ are statistically significant at a 10\%, 5\%, and $1 \%$ confidence level. 


\section{Publications in the Report Series Research* in Management}

\section{ERIM Research Program: "Finance and Accounting"}

\section{4}

Corporate Finance In Europe Confronting Theory With Practice

Dirk Brounen, Abe de Jong and Kees Koedijk

ERS-2004-002-F\&A

http://hdl.handle.net/1765/1111

* A complete overview of the ERIM Report Series Research in Management: https://ep.eur.nl/handle/1765/1

ERIM Research Programs:

LIS Business Processes, Logistics and Information Systems

ORG Organizing for Performance

MKT Marketing

F\&A Finance and Accounting

STR Strategy and Entrepreneurship 